\title{
Reavaliação das condições de cristalização de granitos alcalinos ediacaranos dos domínios Rio Piranhas-Seridó e São José do Campestre, Província Borborema, NE-Brasil
}

Revaluation of the crystallization conditions of ediacaran alkaline granites in the Rio Piranhas-Seridó and São José do Campestre Domains, Borborema Province, NE-Brazil

\author{
Clarissa de Aguiar Dalan¹ (iD), Frederico Castro Jobim Vilalva1 (iD, Marcos Antônio Leite Nascimento ${ }^{1}$ (i) \\ ${ }^{1}$ Universidade Federal do Rio Grande do Norte - UFRN, Programa de Pós-graduação em Geodinâmica e Geofísica, \\ Avenida Senador Salgado Filho, 3.000, Lagoa Nova, Caixa Postal 1596, CEP 59078-970, Natal, RN, BR \\ (clarissa.dalan@gmail.com; frederico@geologia.ufrn.br, marcos@geologia.ufrn.br)
}

Recebido em 17 de agosto de 2018; aceito em 18 de janeiro de 2019

\begin{abstract}
Resumo
As condições de cristalização (P, $\left.\mathrm{T}, f \mathrm{O}_{2}\right)$ de granitos alcalinos (tipo-A) nos domínios Rio Piranhas-Seridó e São José do Campestre (NE da Província Borborema) foram reavaliadas a partir da aplicação simultânea de múltiplos geobaromômetros e geotermômetros e modelagens de cristalização. Os corpos estudados são os plútons Caxexa, Serra do Algodão, Serra do Boqueirão, Olho D’Água, Japi e Serra Negra do Norte e o stock Flores. Os resultados mostram pressões de alojamento entre 3,0 e 3,7 kbar ( 11-14 km em profundidade), à exceção do plúton Japi, com pressões médias de 5,3 kbar ( 20 km). Os modelamentos resultam em temperaturas de liquidus entre $885-917$ e $818^{\circ} \mathrm{C}$ para o stock Flores, e solidus entre 660 e $700^{\circ} \mathrm{C}$. Egirina-augita, magnésio-ferri-hornblenda e biotita cristalizam-se entre $813-822,728-751$ e $750-789^{\circ} \mathrm{C}$, respectivamente. Entre os acessórios, o geotermômetro Zr-em-titanita retorna temperaturas da ordem de $780^{\circ} \mathrm{C}$ (máximas de $830^{\circ} \mathrm{C}$ ) para o plúton Caxexa. A cristalização ocorreu sob condições essencialmente oxidantes para a maioria dos plútons $\left(+1,0<\Delta_{\mathrm{QFM}}\right.$ $<+2,1)$, à exceção do stock Flores, formado sob condições levemente mais reduzidas $\left(\Delta_{\mathrm{OFM}} \approx 0,0\right)$. Os plútons associados a zonas de cisalhamento regionais são mais enriquecidos em álcalis e, em média, mais profundos, reforçando o papel do controle estrutural na colocação e no contraste químico entre os granitos. As novas estimativas são mais acuradas e contribuem para o melhor entendimento da evolução do magmatismo granítico alcalino na porção setentrional da Província Borborema.
\end{abstract}

Palavras-chave: Granitos alcalinos; Geotermobarometria; Província Borborema.

\begin{abstract}
The crystallization conditions ( $\mathrm{P}, \mathrm{T}, f \mathrm{O}_{2}$ ) of alkaline granites (A-type) within the Rio Piranhas-Seridó and São José do Campestre domains (NE Borborema Province) were revaluated based on the simultaneous application of multiple geobarometers, geothermometers and crystallization modelling. The studied bodies are the Caxexa, Serra do Algodão, Serra do Boqueirão, Olho D'Água, Japi, and Serra Negra do Norte plutons, and the Flores stock. The results show emplacement pressures between 3.7 and $3.7 \mathrm{kbar}(\sim 11-14 \mathrm{~km}$ at depth), except for the Japi pluton, with an average pressure of $5.3 \mathrm{kbar}$ ( $\sim 20 \mathrm{~km}$ at depth). Crystallization modelling yield liquidus temperatures in the range between $885-917$ and $818^{\circ} \mathrm{C}$ for the Flores stock, and solidus between $660-700^{\circ} \mathrm{C}$. Aegirine-augite, magnesio-ferri-hornblende and biotite crystallize between $813-822,728-751$, and $750-789^{\circ} \mathrm{C}$, respectively. Among the accessories, the geothermometer $\mathrm{Zr}$-in-titanite yields temperatures of about $780^{\circ} \mathrm{C}$ (maximum of $830^{\circ} \mathrm{C}$ ) for the Caxexa pluton. Crystallization took place under essentially oxidizing conditions for most of the plutons $\left(+1.0<\Delta_{\mathrm{OFM}}<+2.1\right)$, except for the Flores stock, formed under slightly more reduced conditions $\left(\Delta_{\mathrm{QFM}} \approx 0.0\right)$. Plutons related to regional shear zones are alkali-richer and, on average, deeper, reinforcing the role of structural control on the emplacement and chemical contrast among these granites. The new estimates are more accurate and contribute to the better understanding of the evolution of the granitic alkaline magmatism within the setentrional portion of the Borborema Province.
\end{abstract}

Keywords: Alkaline granites; Geothermobarometry; Borborema Province. 


\section{INTRODUÇÃO}

A definição acurada dos parâmetros intensivos de cristalização de magmas graníticos é de extrema importância para a proposição, caracterização e investigação de modelos petrológicos, evolutivos e metalogenéticos. Entre diversos métodos disponíveis, estimativas geotermobarométricas por meio da composição química da rocha hospedeira e de seus principais minerais são as de uso mais frequente (Anderson, 1996; Anderson et al., 2008; Putirka, 2008). Por exemplo, as temperaturas (T) de liquidus de magmas graníticos são estimadas com base nos geotermômetros de saturação em zircão (Watson e Harrison, 1983; Gervasoni et al., 2016) e apatita (Harrison e Watson, 1984), baseados nos conteúdos de $\mathrm{Zr} \mathrm{e} \mathrm{P}_{2} \mathrm{O}_{5}$ em rocha-total, respectivamente. Todavia, esses métodos têm sido recentemente questionados por diversos autores (Harrison et al., 2007; Siégel et al., 2018). Por sua vez, a definição das pressões (P) de alojamento de corpos graníticos (especialmente cálcio-alcalinos) é fundamentada em equilíbrios minerais que seguem a regra das fases de Gibbs (Anderson, 1996; Anderson et al., 2008). Entre eles, o consagrado geobarômetro Al-emhornblenda (Hammarstrom e Zen, 1986; Schmidt, 1992; Anderson e Smith, 1995; Mutch et al., 2016) baseia-se na variação dos teores de $\mathrm{Al}$ em anfibólio como uma função da temperatura e da pressão. As pressões calculadas podem ser combinadas com geotermômetros para a determinação das temperaturas de cristalização, dentre os quais aquele baseado no equilíbrio hornblenda-plagioclásio é o de uso mais amplo (Holland e Blundy, 1994). Contudo, a ausência de hornblenda ou ainda composições não adequadas desse anfibólio (e/ou do plagioclásio em equilíbrio) em diversos corpos graníticos acabam por inviabilizar a adoção desses geotermobarômetros. Esses exemplos mostram que a termobarometria de granitoides não é tarefa trivial, e diversos geotermobarômetros devem ser utilizados em conjunto (respeitando as calibrações e limites de aplicação), a fim de se ter estimativas mais precisas e de significado geológico da pressão, temperatura, além das condições redox de colocação e cristalização.

Para além dos geobarômetros e geotermômetros citados, novas calibrações e modelos permitem estimar T, $\mathrm{P}$ e $\mathrm{fO}_{2}$ com base:

- na composição química de minerais máficos isolados (Ridolfi et al., 2010);

- no equilíbrio com o líquido residual (Putirka, 2008);

- nas concentrações de determinados elementos traços em minerais acessórios (Hayden et al., 2008);

- nos conteúdos normativos de quartzo, albita e ortoclásio (Yang, 2017);

- em simulações de cristalização e modelamentos químicos com o programa rhyolite-MELTS (Gualda et al., 2012; Moecher et al., 2014).
Na porção setentrional da Província Borborema (NE do Brasil), a região compreendida entre os domínios tectonoestruturais São José do Campestre e Rio Piranhas-Seridó é marcada por um extenso e volumoso magmatismo granítico de idade ediacarana a cambriana, representado por batólitos, plútons e corpos menores de afinidades químicas diversas (Nascimento et al., 2015). Entre eles, reconhece-se uma suíte de granitos de afinidade alcalina (tipo-A), sin- a pós-colisionais, cujas condições de cristalização ainda não são bem definidas, ou estimadas com base em critérios qualitativos e/ou indiretos. Este trabalho propõe uma reavaliação dos parâmetros intensivos de cristalização dos granitos alcalinos desses dois domínios a partir da integração de resultados obtidos da aplicação simultânea de múltiplos geotermômetros e geobarômetros clássicos, novas calibrações e modelos, aliados a simulações de cristalização. Com base nas novas estimativas, apresentam-se também algumas considerações geodinâmicas.

\section{CONTEXTUALIZAÇÃO GEOLÓGICA}

A Província Borborema corresponde a um cinturão orogênico meso-neoproterozoico que envolve a colagem de blocos crustais mais antigos (arqueanos a paleoproterozoicos) e unidades supracrustais proterozoicas, agrupadas em diferentes terrenos e domínios tectonoestratigráficos. Em seu extremo nordeste, a província é subdividida em três domínios (Angelim et al., 2006): Jaguaribeano, Rio Piranhas-Seridó (RPS) e São José do Campestre (SJC). Nesta região (e na província como um todo), uma importante feição geológica é a ocorrência de um volumoso magmatismo granítico (lato sensu) sin- a pós-orogênico durante os períodos Ediacarano e Cambriano (Figura 1). Nos Domínios RPS e SJC, esse magmatismo é agrupado em seis suítes com características petrográficas e químicas distintas: shoshonítica, cálcio-alcalina de alto $\mathrm{K}$ porfirítica, cálcio-alcalina de alto $\mathrm{K}$ equigranular, cálcio-alcalina, alcalina e alcalina charnoquítica (Nascimento et al., 2015). A suíte alcalina, tal como inicialmente definida por Nascimento et al. (2015), inclui a fácies alcalina do plúton Japi e os plútons Caxexa, Serra do Algodão, Serra do Boqueirão e Olho D'Água no Domínio SJC, e Serra Negra do Norte no Domínio RPS. Adicionalmente, este trabalho incorpora à suíte o stock Flores (RPS), recentemente estudado por Souza et al. (2017), que reconheceram assinatura de tipo-A para este corpo, anteriormente inserido na suíte cálcio-alcalina de alto K equigranular (Nascimento et al., 2015). As litologias predominantes e idades de cada plúton são apresentadas na Tabela 1. As rochas encaixantes são gnaisses migmatíticos arqueanos a paleoproterozoicos do Domínio SJC e gnaisses migmatíticos paleoproterozoicos do Complexo Caicó e rochas suprascrustais do Grupo Seridó no Domínio RPS (Figura 1). 


\section{MATERIAIS E MÉTODOS}

Dados petrográficos, litoquímicos e de química mineral disponíveis para os plútons estudados, bem como alguns dados ainda inéditos dos autores e pesquisadores associados, foram compilados para a elaboração de um banco de dados. As principais referências consultadas são listadas na Tabela 1.

As informações petrográficas foram checadas e completadas a partir da descrição em microscópio petrográfico de lâminas delgadas dos plútons Caxexa (15 lâminas), Serra
Negra do Norte (11 lâminas) e Flores (32 lâminas) provenientes da coleção dos autores e pesquisadores associados.

Os dados de química mineral de feldspatos (plagioclásio e feldspato alcalino), clinopiroxênios, anfibólios e biotita foram recalculados para se obter as fórmulas estruturais e proporções catiônicas. Nos feldspatos, os cálculos foram feitos na base de 32 oxigênios, considerando $\mathrm{Fe}_{\text {total }}=\mathrm{Fe}^{3+}$ (Deer et al., 2013). Para os piroxênios, a fórmula estrutural e a partição $\mathrm{Fe}^{2+} / \mathrm{Fe}^{3+}$ foram calculadas na base de 4 cátions totais e 6 oxigênios (Droop, 1987). A classificação dos anfibólios segue

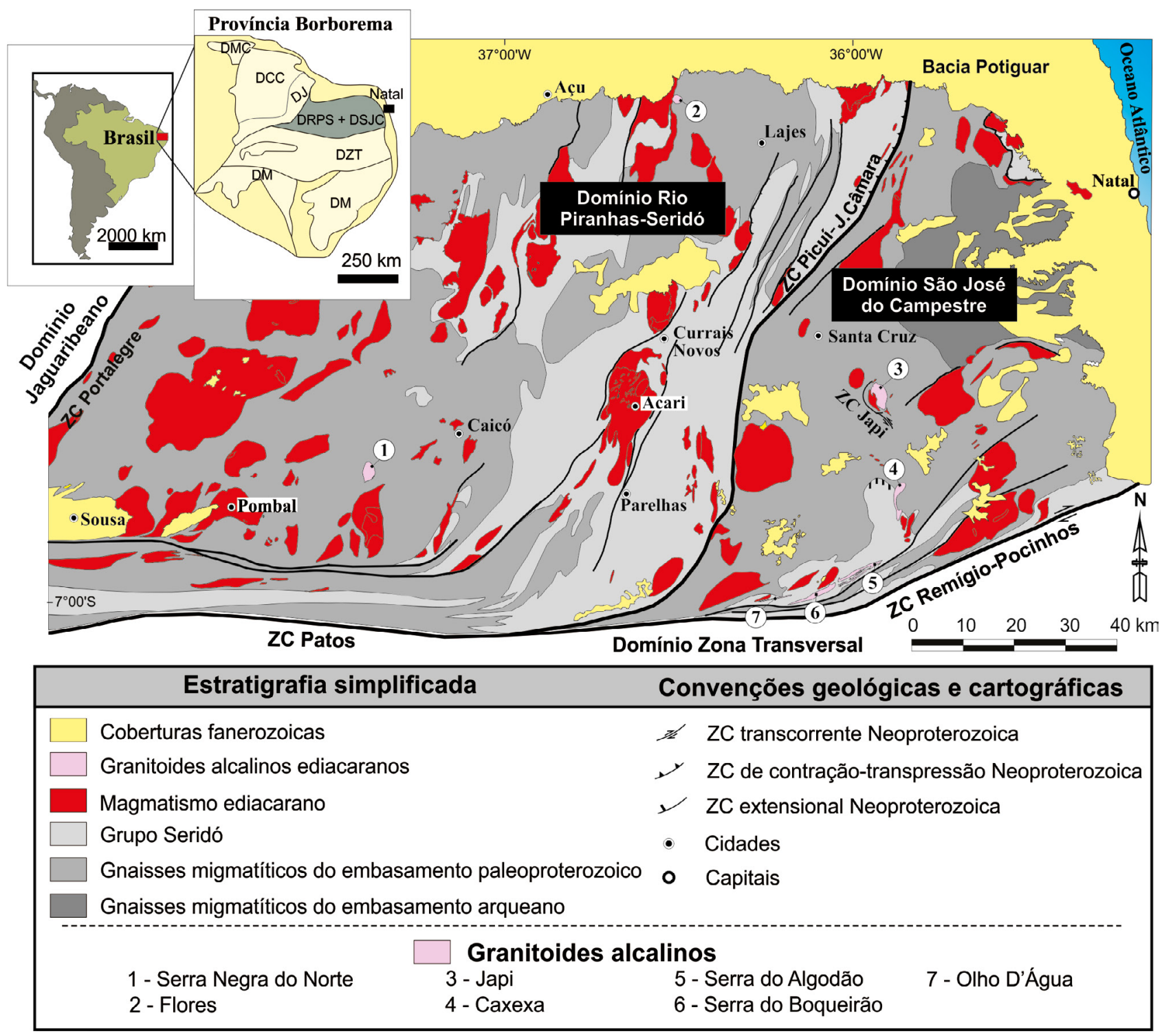

Fonte: modificado de Nascimento et al. (2015). ZC: Zona de cisalhamento.

Figura 1. No topo, à esquerda, localização da Província Borborema e seus domínios tectonoestratigráficos Médio Coreaú (DMC), Ceará Central (DCC), Jaguaribeano (DJ), Zona Transversal (DZT), Meridional (DM), e o conjunto formado pelos domínios Rio Piranhas-Seridó (DRPS) e São José do Campestre (DSJC), em destaque. Esboço geológico dos Domínios Rio Piranhas-Seridó (DRPS) e São José do Campestre (DSJC), com ênfase para o magmatismo ediacarano. Os granitoides alcalinos estudados (em rosa) são identificados pelos números de 1 a 7 . 
as novas recomendações da IMA (Hawthorne et al., 2012). A partição $\mathrm{Fe}^{2+} / \mathrm{Fe}^{3+}$ foi feita pelo método de Schumacher (1997), adotando-se as estimativas máximas de $\mathrm{Fe}^{3+}$. Para a biotita, a fórmula estrutural foi computada na base de 22 oxigênios, assumindo-se $\mathrm{Fe}_{\text {total }}=\mathrm{Fe}^{2+}$ (Dymek, 1983).

Visando à aplicação do geotermômetro Zr-em-titanita de Hayden et al. (2008), os teores de Zr (ppm) em cristais de titanita primária do plúton Caxexa foram quantificados por ablação a laser (laser ablation) no laboratório de LA-ICP-MS do Instituto de Geociências da USP, em um espectrômetro ICP-MS quadrupolo modelo iCAP Q da Thermo Scientific, acoplado a um sistema de laser ablation modelo UP-213 da ESI-New Wave. Quatro cristais de titanita foram analisados em seções delgado-polidas de $100 \mu \mathrm{m}$. Os experimentos de ablação foram feitos com uma fluência de energia de $3,6 \mathrm{~J} / \mathrm{cm}^{2}$, frequência de repetição e diâmetro do laser de $15 \mathrm{~Hz}$ e $40 \mu \mathrm{m}$, respectivamente. O tempo total de aquisição foi de $120 \mathrm{~s}$, igualmente dividido entre leitura do background $\mathrm{e}$ aquisição do sinal iônico do isótopo ${ }^{91} \mathrm{Zr}$, seguido por $30 \mathrm{~s}$ de washout time. O padrão externo foi o NIST-SRM 610, e os teores médios de $\mathrm{CaO}$ (\% peso) na titanita do Caxexa, obtidos via microssonda eletrônica por Nascimento (2000), serviram de padrão interno. A redução dos dados, a correção do drift do equipamento, o tratamento e a conversão das intensidades em concentrações (ppm) foram efetuados com o programa Glitter (van Achterbergh et al., 2001).

\section{Geotermobarometria}

Os dados químicos (rocha-total e química mineral) foram utilizados para calcular os parâmetros intensivos de cristalização (P, T, $f \mathrm{O}_{2}$ ) dos granitos alcalinos dos domínios RPS e SJC. A Tabela 2 lista os geobarômetros e geotermômetros utilizados.
Foram utilizadas diversas calibrações do geobarômetro Al-em-hornblenda. Em todos os casos, a pressão foi calculada independente da temperatura, considerando apenas análises de anfibólios com valores da razão $\mathrm{Fe} /(\mathrm{Fe}+\mathrm{Mg})$ entre 0,4 e 0,65 (Anderson e Smith, 1995). O geobarômetro de Yang (2017) estima a pressão de colocação de magmas graníticos a partir de equações polinomiais baseadas nos conteúdos normativos de quartzo (Qz), albita $(\mathrm{Ab})$ e ortoclásio (Or). Esse geobarômetro foi recentemente testado por Dou et al. (2018), que propuseram uma série de cuidados a serem tomados em sua utilização, os quais são aqui adotados. Adicionalmente, nossos testes mostraram resultados mais robustos e de melhor significado geológico ao se usar as quantidades normativas de $\mathrm{Qz}, \mathrm{Ab}$ e Or corrigidas pelos conteúdos de anortita (An), de acordo com a aproximação de Blundy e Cashman (2001).

O geotermobarômetro de Putirka (2008), baseado no equilíbrio clinopiroxênio-líquido, retornou valores de significado geológico apenas para os plútons Caxexa e Serra do Algodão. Em ambos os casos foram utilizadas análises químicas preferencialmente das bordas dos cristais de clinopiroxênios. A composição da rocha hospedeira desses cristais foi definida como o líquido em equilíbrio.

As simulações de cristalização com o programa rhyolite-MELTS (Gualda et al., 2012) foram feitas a partir dos dados litoquímicos. Uma vez que os plútons são relativamente homogêneos do ponto de vista químico, as composições iniciais utilizadas foram aquelas mais próximas da composição média de cada plúton. Um teor mínimo de $\mathrm{H}_{2} \mathrm{O}$ de $4,0 \%$ foi considerado nos cálculos para os plútons portando anfibólio e/ou biotita (Naney, 1983; Dall'Agnol et al., 1999). Para o plúton Caxexa, um teor mínimo de 2,5\% de $\mathrm{H}_{2} \mathrm{O}$ foi estimado de acordo com Holtz et al. (2001).

Tabela 1. Relação dos plútons alcalinos dos Domínios Rio Piranhas-Seridó e São José do Campestre, Província Borborema, com as respectivas idades, litologias predominantes e referências consultadas.

\begin{tabular}{|c|c|c|c|c|c|}
\hline $\begin{array}{l}\text { Contexto } \\
\text { geotectônico }\end{array}$ & \multicolumn{2}{|c|}{ Domínio Rio Piranhas-Seridó } & \multicolumn{3}{|c|}{ Domínio São José do Campestre } \\
\hline Plúton & $\begin{array}{c}\text { Serra Negra do } \\
\text { Norte }\end{array}$ & Flores & Japi & Caxexa & $\begin{array}{l}\text { Serra do Algodão, } \\
\text { Serra do } \\
\text { Boqueirão, } \\
\text { Olho d'Água }\end{array}$ \\
\hline Idade & $\begin{array}{c}547 \pm 47 \mathrm{Ma} \\
\text { (Rb/Sr rocha-total) } \\
\text { Campos et al. } \\
(2000)\end{array}$ & $\begin{array}{c}553 \pm 4 \text { Ma } \\
(\text { U-Pb zircão) } \\
\text { Souza et al. (2016) }\end{array}$ & $\begin{array}{c}599 \pm 3 \mathrm{Ma} \\
(\text { U-Pb zircão) } \\
\text { Souza et al. (2016) }\end{array}$ & $\begin{array}{c}578 \pm 14 \mathrm{Ma} \\
\text { (Sm/Nd rocha-total) } \\
\text { Nascimento et al. } \\
(2001)\end{array}$ & $\begin{array}{c}529 \pm 54 \mathrm{Ma} \\
\text { (Rb/Sr rocha-total) } \\
\text { Nascimento (1998) }\end{array}$ \\
\hline $\begin{array}{l}\text { Litologias } \\
\text { predominantes }\end{array}$ & $\begin{array}{l}\text { hbl-bt sieno- } \\
\text { monzogranitos, } \\
\text { álcali-feldspato } \\
\text { granitos }\end{array}$ & bt monzogranitos & $\begin{array}{l}\text { hbl-cpx sieno- } \\
\text { monzogranitos }\end{array}$ & $\begin{array}{c}\text { cpx-álcali-feldspato } \\
\text { granitos }\end{array}$ & $\begin{array}{c}\text { cpx-álcali-feldspato } \\
\text { granitos e sienitos, } \\
\text { qz-álcali-feldspato } \\
\text { sienitos }\end{array}$ \\
\hline Referências & $\begin{array}{l}\text { Campos et al. } \\
\text { (2000) }\end{array}$ & $\begin{array}{c}\text { Galindo et al. } \\
\text { (2012); Souza et al. } \\
(2017)\end{array}$ & $\begin{array}{l}\text { Hollanda et al. } \\
\text { (1999) }\end{array}$ & $\begin{array}{l}\text { Nascimento et al. } \\
\text { (2003) }\end{array}$ & $\begin{array}{c}\text { Nascimento et al. } \\
\text { (2003); Nascimento } \\
\text { et al. (2010) }\end{array}$ \\
\hline
\end{tabular}

Ma: milhões de anos; hbl: hornblenda; bt: biotita; qz: quartzo; pl: plagioclásio; cpx: clinopiroxênio. 
Foram modeladas duas amostras de cada plúton. Dada a semelhança petrográfica e química entre os plútons Caxexa, Serra do Algodão, Boqueirão e Olho D'Água, optou-se por utilizar apenas amostras do Plúton Caxexa como representativas desse grupo. As simulações foram isobáricas, considerando as pressões médias obtidas a partir dos geobarômetros listados na Tabela 2. As condições redox foram fixadas no tampão quartzo-faialita-magnetita (QFM). A partir dos dados fornecidos, o programa inicialmente estima a temperatura de liquidus. A modelagem prossegue até a total cristalização da composição considerada. Nesse intervalo são estimadas as temperaturas de cristalização de clinopiroxênio, anfibólio, biotita e zircão, e a temperatura de solidus. Os parâmetros termodinâmicos das fases minerais precipitadas são aqueles disponíveis no próprio programa (Gualda et al., 2012).

Os modelamentos das temperaturas de cristalização de zircão com o rhyolite-MELTS seguem a proposta de Moecher et al. (2014). Para cada intervalo de $5^{\circ} \mathrm{C}$, calculou-se o parâmetro catiônico $\mathrm{M}[(\mathrm{Na}+\mathrm{K}+2 \mathrm{Ca}) /(\mathrm{Al} * \mathrm{Si})$; Watson e Harrison, 1983; Miller et al., 2003] a partir das composições modeladas do líquido em equilíbrio (melt). Com os valores de $\mathrm{M}$, podem-se predizer as temperaturas de saturação em zircão $\left(\right.$ Tsat $_{\mathrm{Zr}}$ ) usando a relação expressa pela Equação 1 (Watson e Harrison, 1983):
$\mathrm{Zr}_{\mathrm{M}, \mathrm{T}}=496.000 \exp \left\{[3,8+(0,85 *(\mathrm{M}-1))]-12.900 \mathrm{~T}\left({ }^{\circ} \mathrm{K}\right)\right\}(1)$

As concentrações de $\mathrm{Zr}$ foram calculadas usando a Equação 2:

$\mathrm{Zr}_{\mathrm{M}, \mathrm{T}}=\mathrm{C}_{0} / \mathrm{F}$

Em que:

$\mathrm{C}_{0}=$ o conteúdo de $\mathrm{Zr}$ (ppm) em rocha-total;

$\mathrm{F}=\mathrm{a}$ fração de líquido $($ melt $)$ remanescente a cada temperatura.

Os modelamentos assumem que o $\mathrm{Zr}$ é incompatível em outras fases minerais até que a saturação em zircão seja alcançada. Dessa forma, a temperatura na qual o zircão inicia sua cristalização é atingida quando $\mathrm{Zr}_{\mathrm{M}, \mathrm{T}}=\mathrm{Zr}_{\text {liquido(melt) }}$.

\section{A SUÍTE ALCALINA: SÍNTESE TEXTURAL E QUÍMICA}

Apresenta-se a seguir uma síntese dos principais aspectos e características geológicas, petrográficas, litoquímicas e de química mineral para os granitos alcalinos dos Domínios SJC e RPS (Tabela 1). Para fins de comparação regional,

Tabela 2. Geobarômetros e geotermômetros utilizados para estimativas de pressão e temperatura dos plútons alcalinos dos Domínios Rio Piranhas-Seridó e São José do Campestre, Província Borborema.

\begin{tabular}{|c|c|c|c|c|c|}
\hline Geotermobarômetros & Abreviações & SNN & Flores & Japi & $\begin{array}{c}\text { Cx, SA, } \\
\text { SB e OD }\end{array}$ \\
\hline \multicolumn{6}{|l|}{ Geobarômetros } \\
\hline Yang (2017) - Qz-Ab-Or normativo & Yang2017 & $\checkmark$ & $\checkmark$ & $\checkmark$ & $\checkmark$ \\
\hline Hammarstrom e Zen (1986) - Al-em-hornblenda & HZ1986 & $\checkmark$ & n.a. & $\checkmark$ & n.a. \\
\hline Johnson e Rutherford (1989) - Al-em-hornblenda & JR1989 & $\checkmark$ & n.a. & $\checkmark$ & n.a. \\
\hline Schmidt (1992) - Al-em-hornblenda & S1992 & $\checkmark$ & n.a. & n.a. & n.a. \\
\hline Mutch et al. (2016) - Al-em-hornblenda & M2016 & $\checkmark$ & n.a. & $\checkmark$ & n.a. \\
\hline \multicolumn{6}{|l|}{ Geotermômetros } \\
\hline Watson e Harrison (1983) - saturação em zircão & Tsat $_{z \mathrm{r}}$ & $\checkmark$ & $\checkmark$ & $\checkmark$ & $\checkmark$ \\
\hline Gualda et al. (2012) - Rhyolite-MELTS liquidus & $\mathrm{T}_{\text {liquidus }}$ & $\checkmark$ & $\checkmark$ & $\checkmark$ & $\checkmark$ \\
\hline Gualda et al. (2012) - Rhyolite-MELTS cristalização de zircão* & TzrMelts & $\checkmark$ & $\checkmark$ & $\checkmark$ & $\checkmark$ \\
\hline Gualda et al. (2012) - Rhyolite-MELTS cristalização de biotita* & TBtMelts & $\checkmark$ & $\checkmark$ & n.a. & n.a. \\
\hline $\begin{array}{l}\text { Gualda et al. (2012) - Rhyolite-MELTS cristalização de } \\
\text { clinopiroxênio* }\end{array}$ & TCpxMelts & $\checkmark$ & n.a. & $\checkmark$ & $\checkmark$ \\
\hline Gualda et al. (2012) -Rhyolite-MELTS cristalização de anfibólio* & THbIMelts & n.a. & n.a. & $\checkmark$ & n.a. \\
\hline Gualda et al. (2012) -Rhyolite-MELTS solidus & $\mathrm{T}_{\text {solidus }}$ & $\checkmark$ & $\checkmark$ & $\checkmark$ & $\checkmark$ \\
\hline Harrison e Watson (1984) - saturação em apatita & TSat $_{\mathrm{ap}}$ & $\checkmark$ & $\checkmark$ & $\checkmark$ & $\checkmark$ \\
\hline Putirka (2008) - clinopiroxênio-líquido & TCpx P08 & $\checkmark$ & n.a. & n.a. & $\checkmark$ \\
\hline Ridolfi et al. (2010) - cristalização de anfibólio & THbl R2010 & $\checkmark$ & n.a. & $\checkmark$ & n.a. \\
\hline Hayden et al. (2008) - Zr-em-titanita & $\mathrm{TZr}_{\text {ttn }}$ & n.a. & n.a. & n.a. & $\checkmark$ \\
\hline $\begin{array}{l}\text { Steiner et al. (1975), Tuttle e Bowen (1958), Luth et al. (1964) } \\
\text { - Qz-Ab-Or normativo (sistema haplogranítico) }\end{array}$ & T Qz-Ab-Or & $\checkmark$ & $\checkmark$ & $\checkmark$ & $\checkmark$ \\
\hline
\end{tabular}

*Temperaturas modeladas de cristalização dos minerais.; n.a.: não aplicado. SNN: Plúton Serra Negra do Norte; Cx: Plúton Caxexa; SA: Plúton Serra do Algodão; SB: Plúton Serra do Boqueirão; OD: Plúton Olho D’Água. 
os dados são confrontados com aqueles disponíveis para granitos de tipo-A no Domínio da Zona Transversal (Figura 1), que incluem basicamente álcali-feldspato granitos e sienitos peralcalinos com riebeckita e egirina-augita do Terreno Piancó-Alto Brígida (plúton Catingueira; Galindo e Sá, 2000), e sieno-monzogranitos meta- a peraluminosos com anfibólio e/ou biotita dos terrenos Alto Moxotó e Alto Pajeú (por exemplo, plútons Queimadas, Pilõezinhos e Bravo; Guimarães et al., 2004; Lages et al., 2016; Lima et al., 2017).

\section{Petrografia e litoquímica}

A suíte alcalina é composta por rochas equigranulares de textura fina a média que definem dois grupos:

- álcali-feldspato granitos, sienitos e sienogranitos subordinados nos plútons do Domínio SJC, cuja mineralogia máfica principal é composta por clinopiroxênio e, por vezes, granada e anfibólio (Figura 2A);

- sieno- a monzogranitos nos corpos intrusivos no Domínio RPS, com textura do tipo granofírica (Figura 2B) e anfibólio e biotita como máficos principais (Figura 2C).

A sequência de cristalização de cada corpo é apresentada na Figura 3. São rochas de caráter peraluminoso a metaluminoso, com afinididades alcalinas a álcali-cálcicas bem marcadas em diagramas litoquímicos (Figura 4). As assinaturas químicas são compatíveis com granitos do tipo-A2 de Eby (1992).

\section{Plútons alcalinos no Domínio São José do Campestre}

- Japi: corpo elipsoidal com $\sim 60 \mathrm{~km}^{2}$, intrusivo na porção central do Domínio SJC e alojado na Zona de
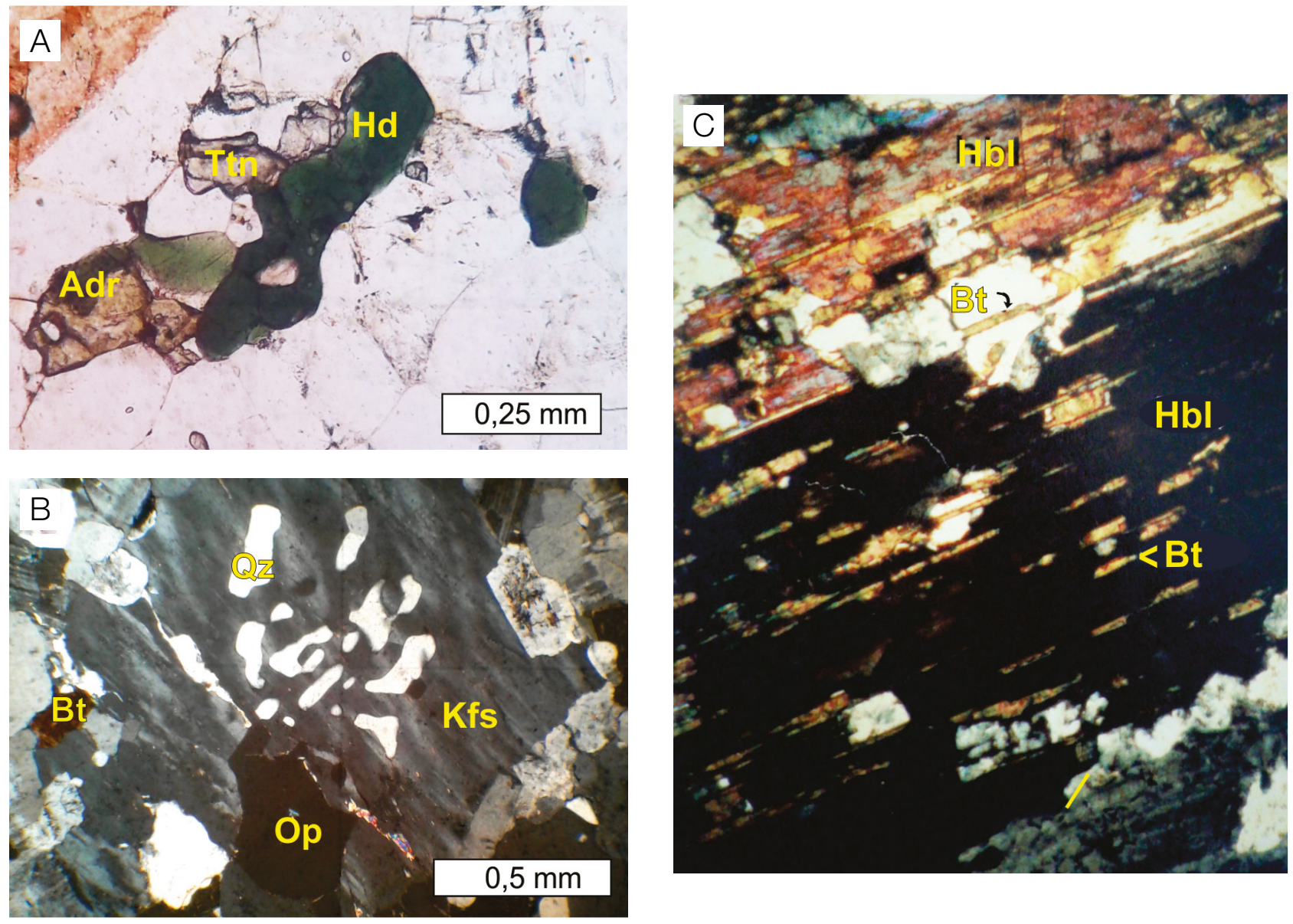

Figura 2. (A) Fotomicrografia a nicóis paralelos da assembleia máfica do plúton Caxexa representada por cristais de hedenbergita (Hd), andradita (Adr) e titanita (Ttn). (B) Assembleia félsica (nicóis cruzados) do stock Flores, com cristais de K-feldspato (Kfs) compondo textura granofírica com quartzo (Qz), além de biotita (Bt), seu máfico principal. Notar também grão de mineral opaco (Op). (C) Fotomicrografia do plúton Serra Negra do Norte (nicóis cruzados com ampliação de 75x, retirada de Campos, 1997) destacando intercrescimento entre hornblenda (Hbl) e biotita (Bt), o que resulta em uma textura poiquilítica para a hornblenda. 
Cisalhamento Japi (Figura 1). Além de uma fácies alcalina, inclui também rochas básico-intermediárias, granitos porfiríticos e leucomicrogranitos. A fácies alcalina inclui sienogranitos, quartzo álcali-feldspato sienitos e quartzo sienitos hololeucocráticos a leucocráticos, com textura equigranular fina. Anfibólios e clinopiroxênios cálcicos são os máficos principais (somando $4 \%$ modal em média). Titanita, apatita, zircão e opacos são acessórios mais importantes. Os parâmetros litoquímicos são: $\mathrm{SiO}_{2}$ entre 67,8 e $76,7 \%$ em peso, $\mathrm{Na}_{2} \mathrm{O}+\mathrm{K}_{2} \mathrm{O}$ entre 8,0 e $10,9 \%$ em peso, razões $\mathrm{A} / \mathrm{CNK}\left[\mathrm{Al}_{2} \mathrm{O}_{3} /\left(\mathrm{CaO}+\mathrm{Na}_{2} \mathrm{O}+\right.\right.$ $\left.\mathrm{K}_{2} \mathrm{O}\right)$ molar] entre 0,88 e 1,07 e fe\# [( $\left.\left.\mathrm{FeO}\right) /(\mathrm{FeO}+\mathrm{MgO})\right]$ entre 0,78 e 0,99 (Hollanda et al., 1999);

- Caxexa: corpo de forma alongada $\left(\sim 50 \mathrm{~km}^{2}\right)$ na direção $\mathrm{N}-\mathrm{S}$, com inflexão para NE na sua porção norte, intrusivo na interface milonítica entre gnaisses migmatíticos do Complexo Caicó e micaxistos do Grupo Seridó, na parte lateral a norte da Zona de Cisalhamento RemígioPocinhos (Figura 1; Jardim de Sá et al., 1999). Estruturas de acamamento magmático e lineamento marcado por minerais máficos são relativamente comuns. Compõe-se de álcali-feldspato granitos hololeucocráticos, com textura equigranular fina, tendo clinopiroxênios cálcicos ou cálcico-sódicos (até 7\% modal) como máficos principais. Andradita (Figura 2A) é uma fase acessória importante (até $4 \%$ modal), além de titanita, apatita, zircão, allanita e magnetita. Os parâmetros litoquímicos são: $\mathrm{SiO}_{2}$ entre $69,0-76,2 \%$ em peso, $\mathrm{Na}_{2} \mathrm{O}+\mathrm{K}_{2} \mathrm{O}$ entre $8,48-10,8 \%$ em peso, e razões A/CNK e fe\# entre $0,92-1,05$ e $0,86-0,98$, respectivamente (Nascimento et al., 2003);

- Serra do Boqueirão, Serra do Algodão e Olho D'Água: corpos relativamente pequenos ( $\sim 30 \mathrm{~km}^{2}$ em média) com formas alongadas na direção NE-SW, alojados ao longo da porção central da Zona de Cisalhamento Remígio-Pocinhos

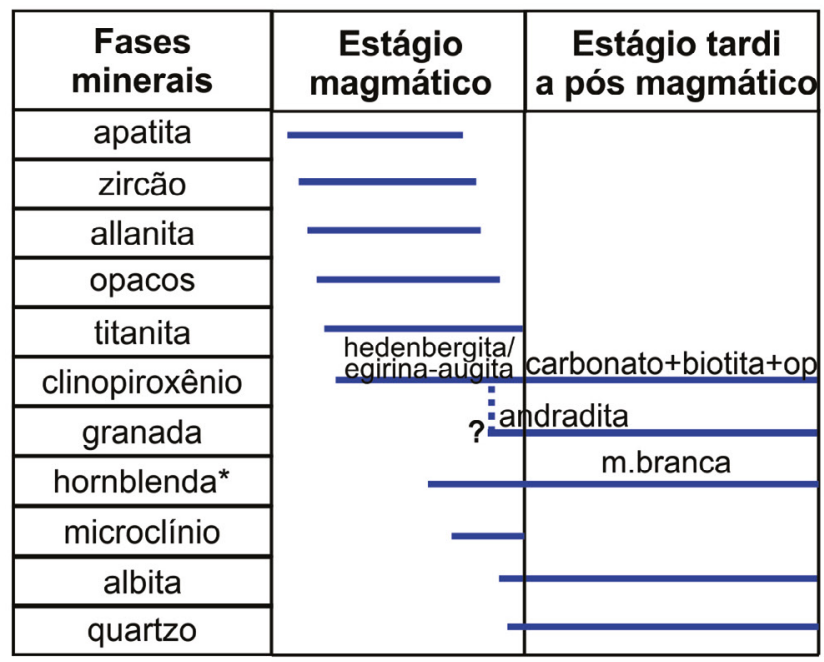

*ocorre somente em uma lâmina do SA.

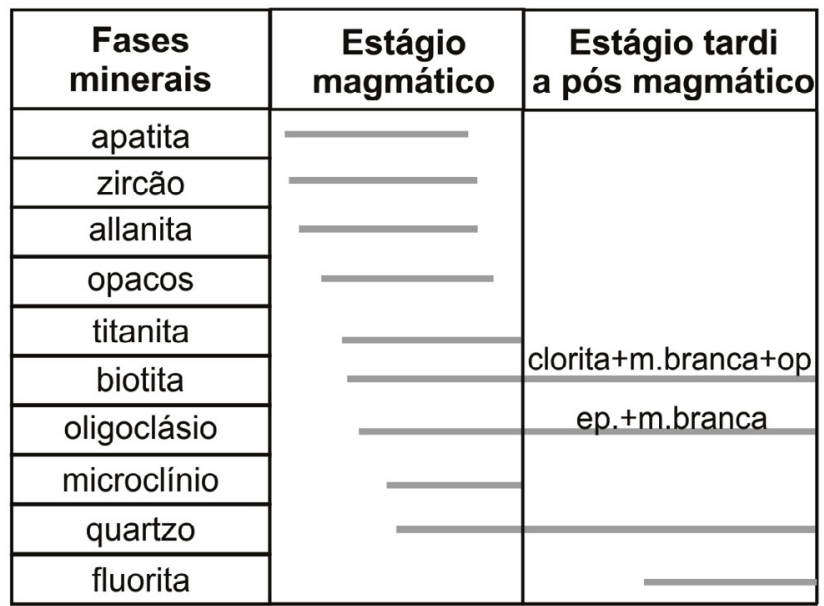

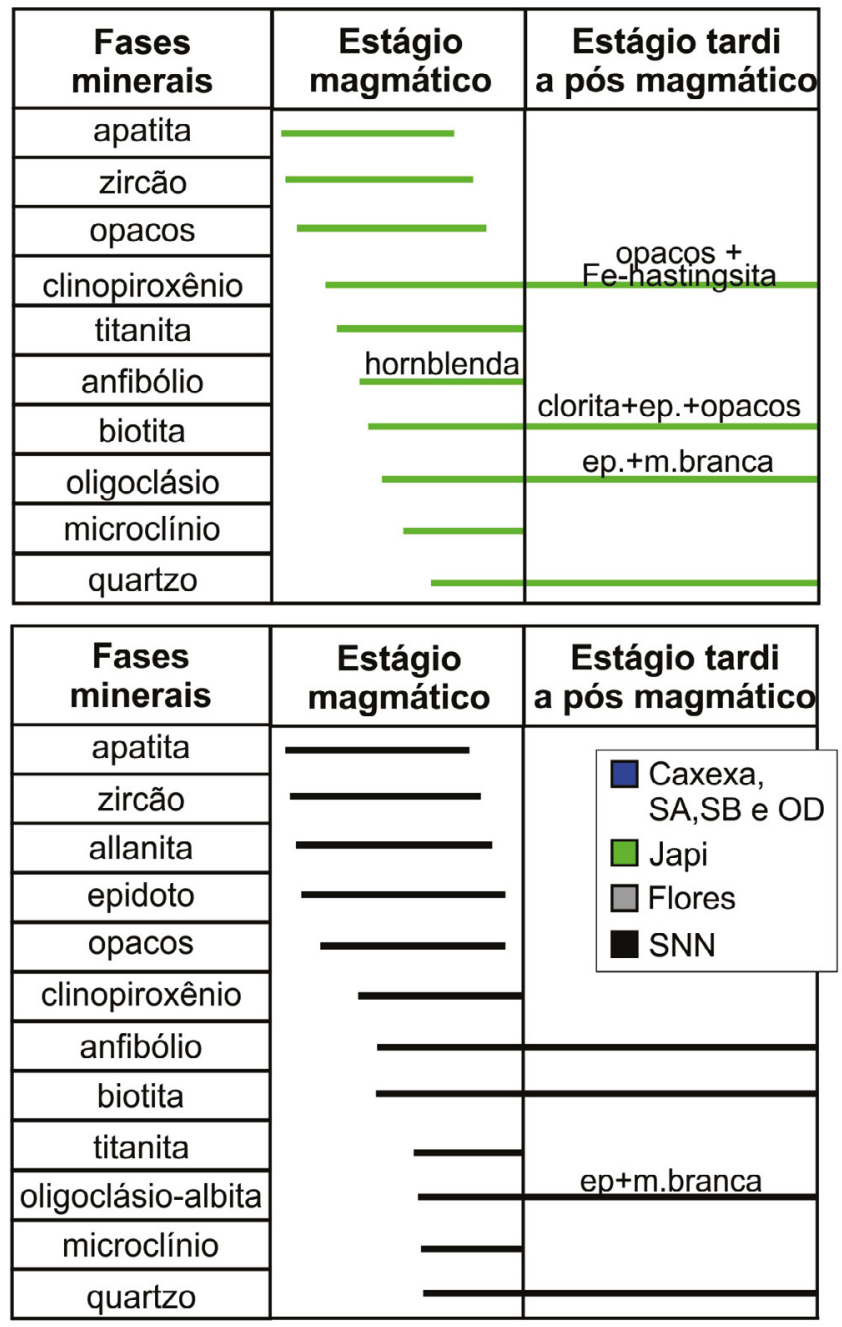

quartzo

op: opacos; m. branca: mica branca; ep.: epidoto; plútons: SA: Serra do Algodão; SB: Serra do Boqueirão; OD: Olho D'Água; SNN: Serra Negra do Norte. Figura 3. Quadros ilustrando as sequências de cristalização dos plútons alcalinos dos Domínios Rio Piranhas-Seridó (RPS) e São José do Campestre (SJC) da Província Borborema. 
(Figura 1) e cortando rochas do Complexo Caicó e Grupo Seridó. As estruturas presentes incluem acamamentos magmáticos e schlieren. Incluem álcali-feldspato granitos e sienitos com mineralogia máfica composta de clinopiroxênio (em média 1,3\% modal) e acessória idêntica ao Caxexa. Os parâmetros litoquímicos são $\mathrm{SiO}_{2}$ entre 68,9 e 76,8\% em peso, $\mathrm{Na}_{2} \mathrm{O}+\mathrm{K}_{2} \mathrm{O}$ entre 9,02 e $11,7 \%$ em peso, A/CNK e fe\# entre $0,94-1,09$ e $0,76-1,0$, respectivamente (Nascimento, 1998; Nascimento et al., 2010).

\section{Plútons alcalinos no Domínio Rio Piranhas-Seridó (RPS)}

- Serra Negra do Norte: corpo levemente elíptico com $\sim 48 \mathrm{~km}^{2}$ de área, intrusivo nos gnaisses-migmatíticos do Complexo Caicó (Figura 1). Estruturas do tipo schlieren e de acamamento magmático são comuns. Engloba três fácies petrográficas:

1. monzo-sienogranitos (fácies predominante) com hornblenda ( $\sim 6 \%$ modal), biotita ( $\sim 3 \%$ modal) como máficos principais (Figura 2C), além de traços de clinopiroxênio cálcico;

2. monzogranitos róseos com hornblenda \pm biotita;

3. diques micrograníticos. Acessórios comuns são titanita, zircão, apatita, allanita, epidoto e magnetita. Os parâmetros litoquímicos são: $\mathrm{SiO}_{2}$ entre 66,2 e $76,23 \%$ em peso, $\mathrm{Na}_{2} \mathrm{O}+\mathrm{K}_{2} \mathrm{O}$ entre 6,24 e $10,4 \%$ em peso, razão A/CNK entre 0,84 e 1,44 e fe\# entre 0,56 e 0,9 (Campos et al., 2000);
- Flores: stock subcircular $\left(\sim 8 \mathrm{~km}^{2}\right)$ levemente alongado na direção NW, intrusivo no Complexo Caicó e em augen gnaisses da suíte Poço da Cruz, na região centro-norte do Domínio RPS. O stock é formado por biotita monzogranitos cinzentos a rosados, equigranulares, de granulação fina a média. É isotrópico, por vezes com estruturas do tipo schlieren, feições de mingling e mixing, além de intercrescimentos granofíricos. Biotita é o máfico principal ( $4 \%$ modal), e os acessórios incluem titanita, apatita, zircão, allanita, magnetita e fluorita. Os parâmetros litoquímicos são: $\mathrm{SiO}_{2}$ entre $71,4 \mathrm{e} 74,8 \%$ em peso, $\mathrm{Na}_{2} \mathrm{O}+\mathrm{K}_{2} \mathrm{O}$ entre 8,26 e $9,08 \%$ em peso, e razões A/CNK e fe\# entre 0,98 1,08 e $0,80-0,94$, respectivamente (Souza et al., 2017).

\section{Quimismo mineral}

\section{Mineralogia félsica}

Nos plútons Caxexa, Japi e Serra do Algodão/Boqueirão/ Olho D’Água, os feldspatos são ortoclásio/microclínio $\left(\mathrm{An}_{0} \mathrm{Ab}_{3-9} \mathrm{Or}_{91-97}\right)$ e albita com composições próximas ao membro-final $\left(\mathrm{An}_{0-9} \mathrm{Ab}_{90-99} \mathrm{Or}_{1-5}\right)$ (Nascimento et al., 2003; Nascimento et al., 2010). No plúton Serra Negra do Norte, o microclínio possui composições entre $\mathrm{An}_{0-1} \mathrm{Ab}_{2-11} \mathrm{Or}_{88-97}$ e o plagioclásio varia de albita a oligoclásio sódico $\left(\mathrm{An}_{1}\right.$. $\left.{ }_{9} \mathrm{Ab}_{90-99} \mathrm{Or}_{0-2} \mathrm{a} \mathrm{An}_{10-19} \mathrm{Ab}_{80-88} \mathrm{Or}_{1-2}\right)($ Campos et al., 2000). Já no stock Flores, o plagioclásio típico é um oligoclásio sódico $\left(\mathrm{An}_{12-13} \mathrm{Ab}_{85-87} \mathrm{Or}_{1-2}\right)$ (Galindo et al., 2012).
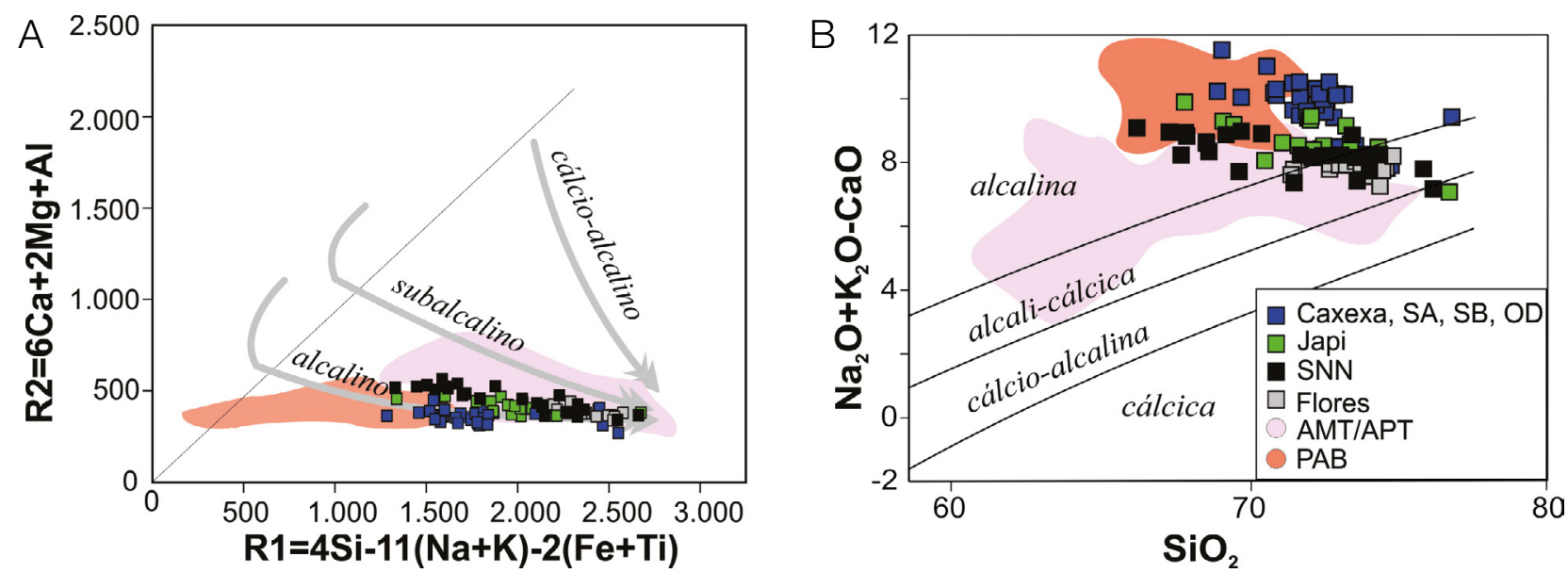

SA: Serra do Algodão; SB: Serra do Boqueirão; OD: Olho D’Água; SNN: Serra Negra do Norte; AMT/APT: Terrenos Alto Moxotó/Alto Pajeú (Zona Transversal); PAB: Piancó-Alto Brígida (Zona Transversal).

Figura 4. Diagramas discriminantes de séries magmáticas para os granitos alcalinos dos Domínios Rio Piranhas-Seridó (RPS) e São José do Campestre (SJC) da Província Borborema. Granitos de tipo-A da Zona Transversal (Terrenos Alto Moxotó/Alto Pajeú e Piancó-Alto Brígida) são também plotados para comparação regional. (A) Diagrama catiônico R1-R2 (De La Roche et al., 1980) destacando o alinhamento dos plútons estudados com a trajetória típica de rochas da série alcalina. (B) Diagrama $\mathrm{SiO}_{2}$ versus $\mathrm{Na}_{2} \mathrm{O}+\mathrm{K}_{2} \mathrm{O}-\mathrm{CaO}$ (\% em peso; Frost et al., 2001) mostrando a afinidade alcalina a álcali-cálcica dos plútons estudados. 


\section{Mineralogia máfica}

Clinopiroxênios são os máficos principais nos plútons Caxexa, Serra do Algodão/Boqueirão/Olho D'Água. São do tipo hedenbergita $\left(\mathrm{Wo}_{50-53} \mathrm{En}_{10-17} \mathrm{Fs}_{32-39}\right)$ ou egirina-augita (Caxexa: $\mathrm{Eg}_{40-48} \mathrm{Jd}_{0-2} \mathrm{WEF}_{53-58}$; Serra do Algodão: $\mathrm{Eg}_{30-31} \mathrm{Jd}_{3-4} \mathrm{WEF}_{65-67}$, em que $\mathrm{WEF}=$ wollastonita + enstatita + ferrossilita $)$. Esta última aparece em amostras que não contêm andradita. Quando essa granada é formada, o clinopiroxênio em paragênese é a hedenbergita (Nascimento et al., 2003). Já nos plútons Japi e Serra Negra do Norte, os clinopiroxênios são ora fase máfica principal em conjunto com anfibólios (Japi), ora fase acessória (Serra Negra do Norte). Classificam-se como diopsídio e augita, com composições entre $\mathrm{Wo}_{48-51} \mathrm{En}_{33-}$ ${ }_{36} \mathrm{Fs}_{16}$ (Japi) e $\mathrm{Wo}_{32-49} \mathrm{En}_{31-50} \mathrm{Fs}_{18-25}$ (Serra Negra do Norte).

$\mathrm{O}$ diagrama ternário Na-Mg-( $\left.\mathrm{Fe}^{2+}, \mathrm{Mn}\right)$ pode ser utilizado para se verificar trajetórias evolutivas de piroxênios em um mesmo plúton ou em plútons de uma mesma suíte (Figura 5A). Para os granitos estudados, infere-se uma trajetória evolutiva marcada inicialmente pelo enriquecimento progressivo em ferro, de forma mais clara para os piroxênios cálcicos dos plútons Serra Negra do Norte, Japi, Caxexa e Serra do Algodão. Em um segundo estágio, a trajetória evolutiva prossegue com um enriquecimento em sódio, resultando nas composições mais evoluídas da egirina-augita dos plútons Caxexa e Serra do Algodão. Trajetórias como esta são descritas na literatura em diversas rochas alcalinas saturadas e supersaturadas ao redor do globo (Bonin e Giret, 1984; Njonfang e Nono, 2003; Gualda e Vlach, 2007).

Anfibólios são encontrados nos plútons Japi e Serra Negra do Norte. Correspondem, em linhas gerais, a Mg-ferrihornblenda, com $\mathrm{Mg}$ sempre maior que 2,0 cpfu e $\mathrm{Al}_{\text {total }}$ entre 0,476 e $1,658 \mathrm{cpfu}$. A razão fe\# $(\mathrm{Fe} / \mathrm{Fe}+\mathrm{Mg})$ varia entre 0,27 e 0,52 . Actinolita é ocasional no plúton Serra Negra do
A

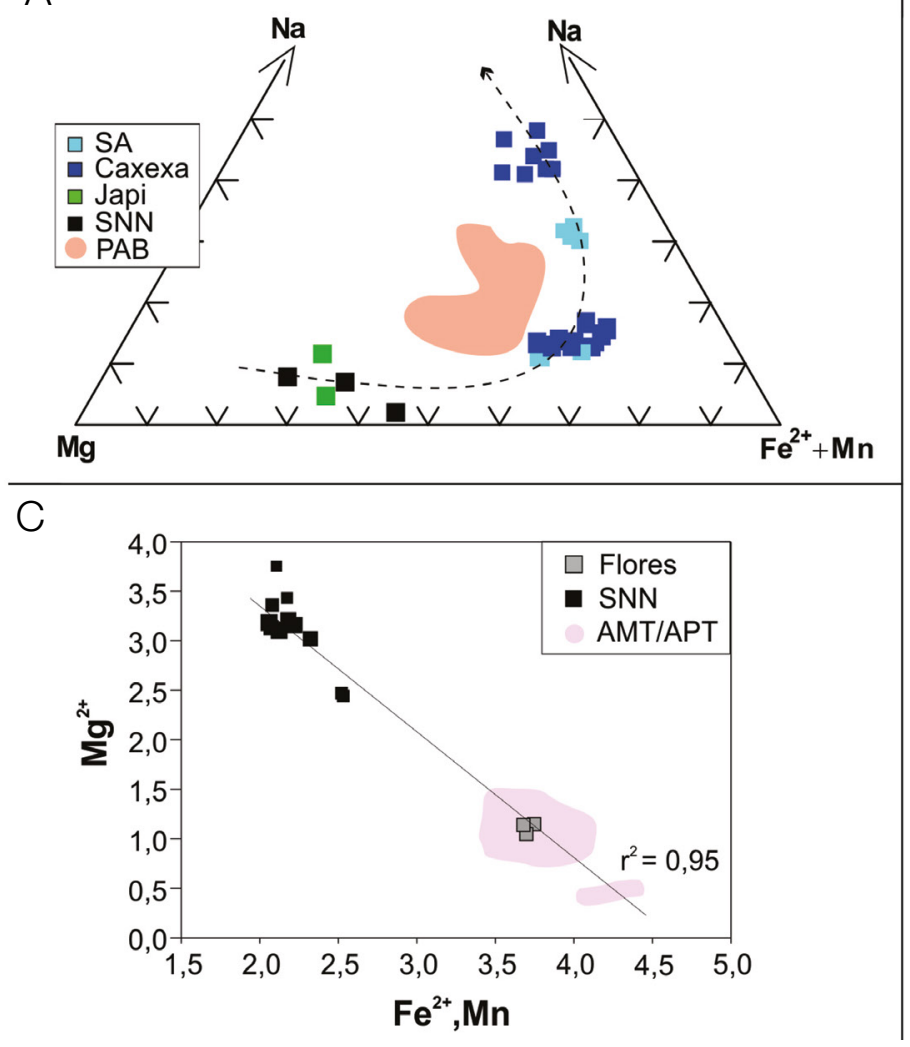

$\mathrm{B}$
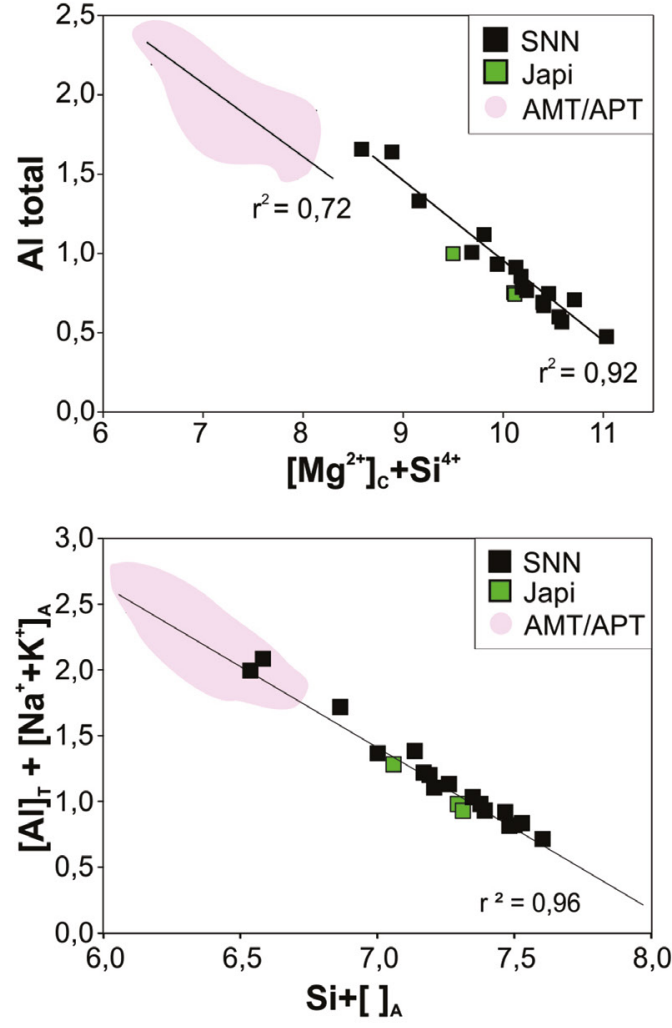

PAB: Terreno Piancó-Alto Brígida (Zona Transversal); AMT/APT: Terrenos Alto Moxotó/Alto Pajeú (Zona Transversal).

Figura 5. Diagramas de variação catiônica para os principais minerais máficos dos granitos alcalinos dos Domínios Rio Piranhas-Seridó (RPS) e São José do Campestre (SJC) da Província Borborema. Os diagramas também mostram as variações químicas nos piroxênios de granitos de tipo-A da Zona Transversal (Terrenos Alto Moxotó/Alto Pajeú e PiancóAlto Brígida) para comparação regional. (A) Diagrama catiônico $\mathrm{Na}-\mathrm{Mg}-\left(\mathrm{Fe}^{2+}, \mathrm{Mn}\right)(\mathrm{cpfu})$ para clinopiroxênios ilustrando possível trajetória evolutiva para o conjunto dos dados. (B) Diagramas binários catiônicos (cpfu) para os anfibólios dos granitos estudados ilustrando as substituições tschermakítica, $\left[\mathrm{Mg}^{2+}\right]_{\mathrm{C}}+\mathrm{Si}^{4+} \leftrightarrow \mathrm{Al}_{\text {total }}$; e edenítica $\mathrm{Si}^{4+}+[]_{\mathrm{A}} \leftrightarrow[\mathrm{Al}]_{\mathrm{T}}+$ $\left[\mathrm{Na}^{+}+\mathrm{K}^{+}\right]_{\mathrm{A}}$, em que [ ] = vacância. (C) Diagrama de substituição catiônica Fe ${ }^{2+}(+\mathrm{Mn}) \leftrightarrow \mathrm{Mg}^{2+}$ (cpfu) para a biotita dos granitos estudados. Plútons: Serra do Algodão (SA), Serra Negra do Norte (SNN). 
Norte. É de cristalização tardia/subsolidus (Campos et al., 2000), como bordas em torno de hornblenda. Caracteriza-se pelos teores mais baixos de $\mathrm{Al}_{\text {total }}(0,476-0,692 \mathrm{cpfu})$. Actinolita tardia também é descrita no plúton Serra do Algodão (Nascimento, 1998). As variações composicionais observadas são satisfatoriamente modeladas pelas substituições tschermakítica e edenítica (Hammarstrom e Zen, 1986; Anderson e Smith, 1995; Deer et al., 2013; Figura 5B).

Biotita é o máfico principal no stock Flores e no plúton Serra Negra do Norte (em paragêneses com anfibólio). Possui composições mais anníticas no stock Flores (Figura 5C; Galindo et al., 2012), com razão fe\# $\sim 0,8$. No plúton Serra Negra do Norte, a biotita é mais magnesiana (Figura 5C) e ocorre intercrescida com anfibólio (Campos et al., 2000), com razão fe\# variando entre 0,38 e 0,51 .

\section{RESULTADOS E DISCUSSÃO}

Apresentam-se na Tabela 3 as estimativas de pressão e temperatura para os granitos alcalinos dos Domínios São José do Campestre (SJC) e Rio Piranhas-Seridó (RPS), obtidas a partir dos geotermobarômetros listados na Tabela 2. A seguir, os resultados são interpretados e discutidos de forma integrada.

\section{Pressão}

As estimativas barométricas obtidas mostram uma maior variação no intervalo $2,0-6,0 \mathrm{kbar}$, com os menores valores concentrados no stock Flores e os maiores no plúton Japi. Pressões fora deste intervalo incluem uma estimativa mínima de 1,3 kbar, e uma máxima de 7,2 kbar para os plútons Serra Negra do Norte e Japi, respectivamente (geobarômetro de Yang, 2017). A partir das estimativas individuais foram calculadas as pressões médias finais de colocação $\left(\mathrm{P}_{\text {média }}\right.$ final) listadas na Tabela 3. Os valores mostram que a maioria dos granitos alcalinos dos Domínios RPS e SJC se cristalizou sob pressões entre 3,0 e 3,7 ( \pm 1$)$ kbar, à exceção do plúton Japi, com pressões médias acima de $5,0 \mathrm{kbar}$, porém no limite do intervalo considerando o desvio padrão associado (Tabela 3 ). Esses valores coincidem com as estimativas das condições do pico metamórfico dos gnaisses migmatíticos encaixantes, estimadas como transicionais entre as fácies anfibolito superior e granulito (3,8-5,7 kbar) para rochas do Domínio SJC (Souza et al., 2006). Já quando comparados com granitos de tipo-A do Domínio da Zona Transversal, os valores são ligeiramente inferiores às pressões de colocação dos plútons dos terrenos Alto Moxotó (AMT) e Alto Pajeú (APT), com um valor médio de 5,0 $\pm 1,2$ kbar (Tabela 3).

Tabela 3. Estimativas barométricas (em kbar), médias parciais e desvios padrão associados e respectiva pressão média geral $\left(P_{\text {média }}\right.$ final) para os granitos alcalinos dos Domínios Rio Piranhas-Seridó e São José do Campestre, Província Borborema. São também listadas as estimativas para granitos tipo-A da Zona Transversal (Terrenos Alto Moxotó/Alto Pajeú) para comparação. Plútons: SA: Serra do Algodão; SB: Serra do Boqueirão; OD: Olho D’Água; AMT/APT: Terrenos Alto Moxotó/Alto Pajeú. Abreviações dos geobarômetros conforme Tabela 2.

\begin{tabular}{|c|c|c|c|c|c|}
\hline $\begin{array}{l}\text { Geobarômetro } \\
\mathrm{P} \text { (kbar) mínima - máxima } \\
P \text { média parcial (kbar) } \pm \text { desvio padrão } \\
\text { número de amostras/análises }\end{array}$ & $\begin{array}{c}\text { Serra Negra } \\
\text { do Norte }\end{array}$ & Flores & Japi & $\begin{array}{c}\text { Caxexa, } \\
\text { SA, SB, OD }\end{array}$ & AMT/APT \\
\hline Yang2017 & $\begin{array}{c}1,3-6,3 \\
3,9 \pm 1,5 \\
N=12 \\
2,8-4,4\end{array}$ & $\begin{array}{c}1,9-4,2 \\
3,0 \pm 0,8 \\
N=15\end{array}$ & $\begin{array}{c}2,0-7,2 \\
5,3 \pm 1,6 \\
N=5\end{array}$ & $\begin{array}{c}1,7-5,7 \\
3,7 \pm 1,3 \\
N=7\end{array}$ & $\begin{array}{c}2,0-8,5 \\
4,2 \pm 1,6 \\
N=36 \\
3,7-8,3\end{array}$ \\
\hline HZ1986 & $\begin{array}{c}3,8 \pm 0,8 \\
N=3\end{array}$ & - & - & - & $\begin{array}{c}5,9 \pm 1,2 \\
N=45\end{array}$ \\
\hline JR1989 & $\begin{array}{c}2,2-3,6 \\
3,1 \pm 0,6 \\
N=3\end{array}$ & - & - & - & $\begin{array}{c}2,4-6,8 \\
4,8 \pm 1,0 \\
N=45\end{array}$ \\
\hline S1992 & $\begin{array}{c}3,3-4,9 \\
4,3 \pm 0,7 \\
N=3\end{array}$ & - & - & - & $\begin{array}{c}3,6-8,6 \\
6,3 \pm 1,1 \\
N=45\end{array}$ \\
\hline M2016 & $\begin{array}{c}1,8-3,8 \\
3,4 \pm 0,5 \\
N=4\end{array}$ & - & - & - & $\begin{array}{c}3,3-7,2 \\
5,0 \pm 0,9 \\
N=45\end{array}$ \\
\hline P2008 & - & - & - & $\begin{array}{c}2,6-4,3 \\
3,6 \pm 0,5 \\
N=9\end{array}$ & - \\
\hline$P_{\text {média }}$ final (kbar) & $3,7 \pm 0,9$ & $3,0 \pm 0,8$ & $5,3 \pm 1,6$ & $3,6 \pm 1,0$ & $5,0 \pm 1,2$ \\
\hline
\end{tabular}


A pressão calculada para o plúton Serra Negra do Norte é inferior aos valores de Campos et al. (2000), entre 4,7 e 5,1 \pm 0,6 kbar, obtidos com a calibração de Schmidt (1992) do barômetro Al-em-hornblenda, contudo observa-se a partir dos dados compilados que a maioria dos anfibólios apresenta composições fora do intervalo de $0,4 \leq$ fe\# $\leq 0,65$ recomendado por Anderson e Smith (1995) e, de fato, apenas uma análise resultou em pressões em torno desses valores com barômetros Al-em-hornblenda. A aplicação do geobarômetro normativo de Yang (2017) para esse plúton retornou pressões de cristalização entre 1,3 e 6,3 \pm 1,5 kbar, os maiores valores compatíveis com Campos et al. (2000) obtidos para monzogranitos róseos com hornblenda, enquanto os sienogranitos principais e microgranitos retornam pressões mais baixas, majoritariamente entre 2,0 e 4,5 \pm 0,9 kbar, valores estes que são mais compatíveis com os resultados obtidos com diversas calibrações do geobarômetro Al-em-hornblenda (Tabela 3). Dessa forma, entende-se que uma pressão média de 3,7 \pm 0,9 kbar seja mais adequada para o plúton Serra Negra do Norte. Campos et al. (2000) chamam ainda a atenção para a presença de epidoto magmático em rochas do plúton (molécula pistacita entre 27 e 29\%), o que demandaria pressões entre 5 e 6 kbar para a estabilização desse mineral (Zen e Hammarstrom, 1988; Schmidt e Thompson, 1996). Contudo, em condições mais oxidantes de cristalização, tal como no caso do Serra Negra do Norte, epidoto é fase magmática estável em pressões tão baixas quanto 3,0 kbar (Sial et al., 2008; Ferreira et al., 2011).

As estimativas barométricas apresentadas para o plúton Caxexa, em conjunto com os plútons Serra do Algodão/ Boqueirão e Olho D'Água, são inéditas. Nascimento (2000) apresenta estimativas indiretas entre 5,4-5,6 \pm 0,2 kbar para o plúton Caxexa a partir do barômetro Al-em-hornblenda (calibrações de Hollister et al., 1987; Schmidt, 1992) em anfibólio-biotita microgranitos que cortam as rochas desse plúton. As análises utilizadas pelo autor foram recalculadas conforme os procedimentos descritos no item 3 , o que resultou em valores ligeiramente menores de $\mathrm{Al}$. Como consequência, tem-se uma estimativa de pressão de 4,7 $\pm 0,6$ kbar para esses microgranitos com os barômetros Al-em-hornblenda da Tabela 2. Esse valor sobrepõe-se às nossas estimativas para os plútons Caxexa, Serra do Algodão/Boqueirão e Olho D’Água, com média de 3,6 \pm 1,0 kbar (Tabela 3) interpretada como a pressão de cristalização desses plútons. Esses valores de pressão estão próximos das estimativas máximas de 3,0 kbar para o plúton peralcalino Catingueira e corpos satélites, ao longo do lineamento Patos no Terreno Piancó-Alto Brígida do Domínio da Zona Transversal (Cunha et al., 2018).

A pressão média de 5,3 \pm 1,6 kbar para o plúton Japi é ligeiramente maior que nos demais plútons estudados, assemelhando-se aos valores médios nos granitos de tipo-A nos terrenos AMT e APT da Zona Transversal, porém estimativas tão altas quanto 7,2 kbar são registradas com o barômetro de Yang (2017) para o Japi, o que pode sugerir cristalização inicial em profundidades maiores, seguida da ascensão do magma para níveis crustais mais rasos controlada pela Zona de Cisalhamento Japi (Figura 1; Hollanda et al., 1999).

Para o stock Flores, as pressões de cristalização são invariavelmente mais baixas, com média de 3,0 $\pm 0,8$ kbar. Tais pressões sugerem que esse corpo se colocou em níveis crustais mais rasos em comparação com as demais intrusões estudadas, num contexto tardi a pós-tectônico (Souza et al., 2017). Tal inferência é embasada por feições petrográficas como a presença relativamente comum de intercrescimentos granofíricos no stock. Ademais, nossas estimativas sobrepõem-se com as pressões entre 3,0 e 5,0 kbar estimadas por Souza et al. (2017) para esse corpo a partir do diagrama ternário Qz-Ab-Or (Tuttle e Bowen, 1958).

\section{Temperatura}

A fim de se obter um panorama termal completo da cristalização dos granitos estudados, diversos geotermômetros distintos foram aplicados, e os resultados foram completados com as simulações de cristalização no programa rhyolite-MELTS (Gualda et al., 2012). As simulações foram particularmente importantes para a melhor caracterização das condições iniciais de cristalização, bem como para a melhor definição das temperaturas de cristalização dos máficos principais.

Resultados disponíveis na literatura para os plútons em questão (Nascimento, 2000; Campos et al., 2000; Nascimento et al., 2010; Souza et al., 2017) estimam a $\mathrm{T}_{\text {liquidus }}$ de forma indireta a partir da temperatura de saturação do zircão (Tsat Watson e Harrison, 1983), assumindo todos os grãos presentes como autocristais. Inferências como essas têm sido alvo de criticismo em contribuições recentes que argumentam que, em magmas graníticos, em poucas circunstâncias há a cristalização do zircão em temperaturas próximas do liquidus. Ao contrário, de forma mais realista, sua formação ocorre ao longo de um amplo intervalo de temperaturas (Harrison et al., 2007; Moecher et al., 2014). Siégel et al. (2018) enfatizam que a principal armadilha nesse caso é que a Tsat ${ }_{\mathrm{zr}}$ é uma temperatura teórica e dinâmica (i.e., varia com a cristalização fracionada) que não necessariamente corresponde à temperatura inicial de cristalização do zircão; tampouco, pois, é uma medição real da $\mathrm{T}_{\text {liquidus }}$. $\mathrm{O}$ que de fato a $\mathrm{Tsat}_{\mathrm{zr}}$ representa é a temperatura na qual a saturação em zircão é alcançada em um magma em processo de cristalização, que pode ser atingida a qualquer momento entre o liquidus e o solidus. De fato, Harrison et al. (2007) mostram que as Tsat $_{z r}$ calculadas de acordo com Watson e Harrison (1983) podem ser cerca de $80-100^{\circ} \mathrm{C}$ inferiores (ou mesmo ainda mais baixas) que as temperaturas de cristalização do zircão.

Para contornar essa situação, as $\mathrm{T}_{\text {liquidus }}$ e as temperaturas de cristalização do zircão (TzrMelts) foram modeladas com o rhyolite-MELTS de acordo com a metodologia de Moecher 
et al. (2014) (Figura 6). Os resultados (Tabela 4) são aqui interpretados como valores mais realistas dos estágios iniciais da cristalização dos granitos alcalinos dos domínios SJC e RPS.

As estimativas termométricas médias e os respectivos desvios padrão são apresentados na Tabela 4 e nos diagramas da Figura 7. Abrangem desde a $\mathrm{T}_{\text {liquidus }}$ até a $\mathrm{T}_{\text {solidus }} \mathrm{e}$
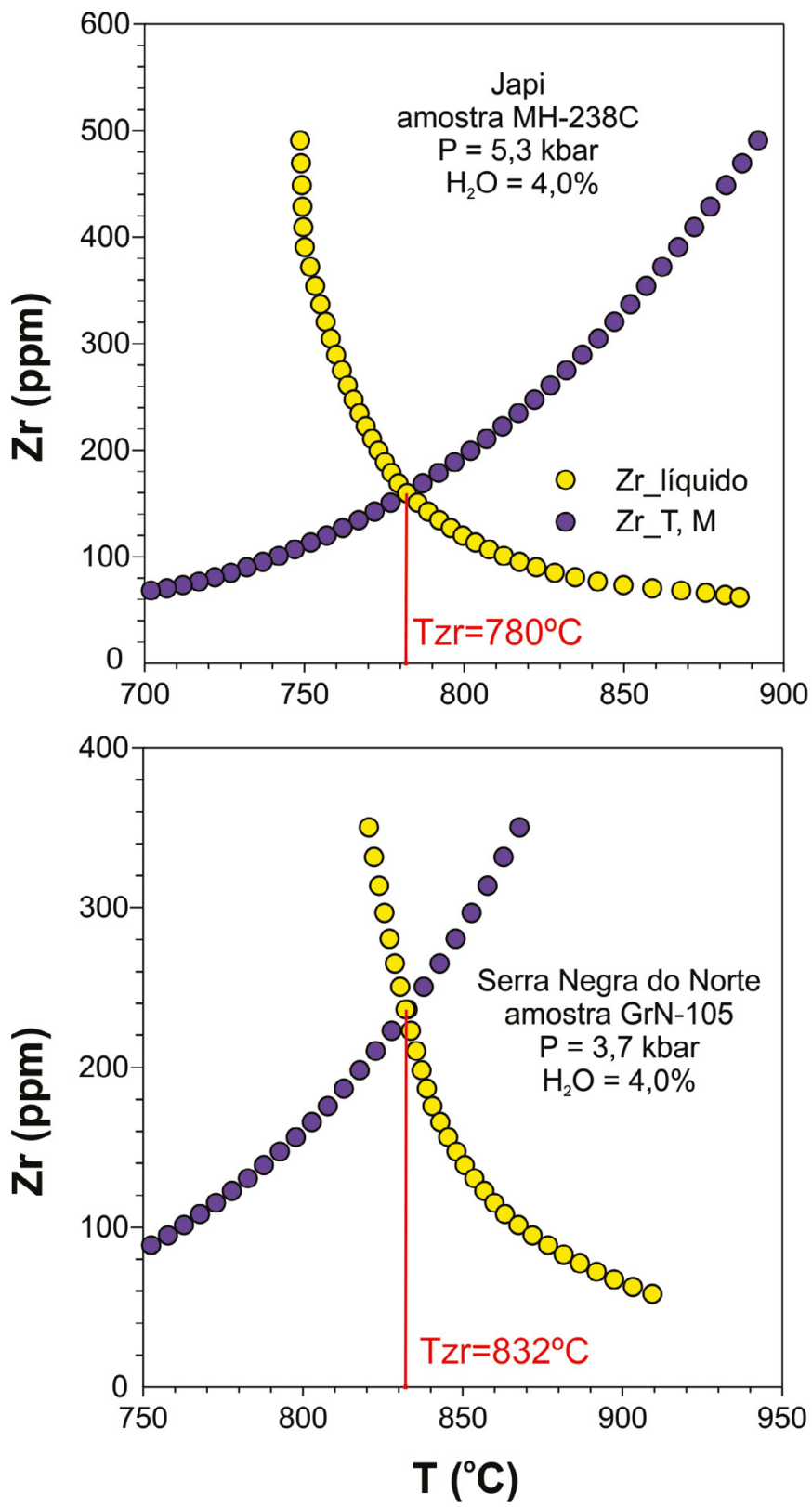

refletem com precisão a sequência de cristalização dos plútons estudados (Figura 3) que, em linhas gerais, é marcada pelo aparecimento precoce de apatita e zircão, seguidos da cristalização de titanita, outros acessórios e, quando presente, clinopiroxênio. Sob temperaturas mais baixas, precipitam-se anfibólios, seguidos de biotita, feldspato e quartzo (Figura 7).
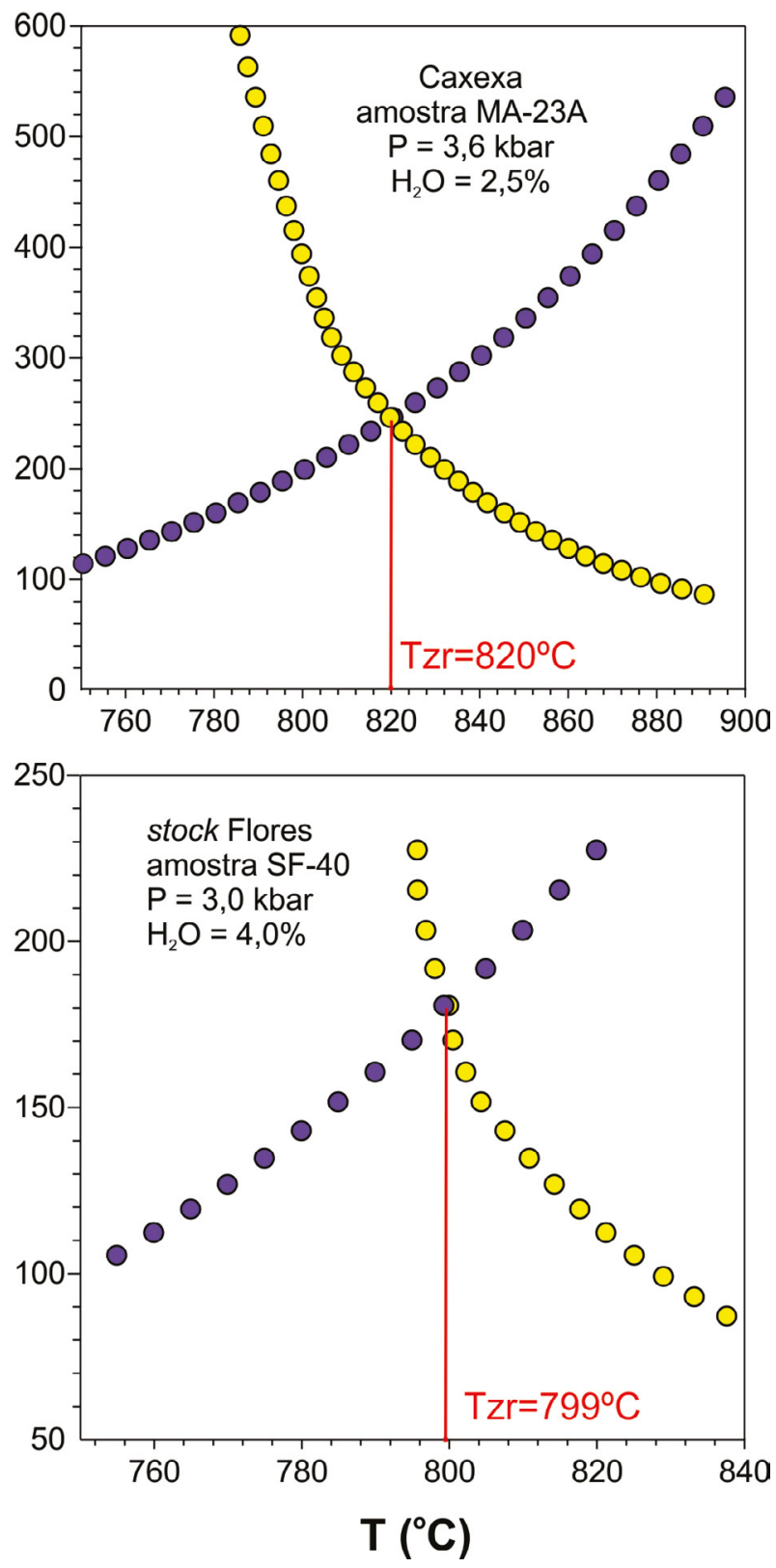

T: temperatura.

Figura 6. Exemplos de resultados da estimativa da temperatura de cristalização de zircão (TzrMelts) para os granitos alcalinos dos Domínios Rio Piranhas-Seridó (RPS) e São José do Campestre (SJC) da Província Borborema por meio de modelagens de cristalização com o programa rhyolite-MELTS, de acordo com a metodologia de Moecher et al. (2014). Círculos roxos $\left(\mathrm{Zr} \_\mathrm{T}, \mathrm{M}\right)$ mostram as concentrações de $\mathrm{Zr}(\mathrm{ppm})$ calculadas a partir do parâmetro M (Watson e Harrison, 1983 ) a cada $5^{\circ} \mathrm{C}$. Círculos amarelos (Zr_líquido) mostram as concentrações de $\mathrm{Zr}$ (ppm) nos líquidos residuais a cada $5^{\circ} \mathrm{C}$, a partir do conteúdo de $\mathrm{Zr}$ medido em rocha-total (condições iniciais). As amostras utilizadas nos modelamentos foram retiradas, na sequência em que aparecem, de Hollanda (1998), Nascimento (2000), Campos (1997) e Souza (2016). 
As temperaturas de liquidus modeladas variam de $818 \pm$ $2^{\circ} \mathrm{C}$ para o stock Flores até $917 \pm 24^{\circ} \mathrm{C}$ para o plúton Serra Negra do Norte. Para os plútons Japi, Caxexa e demais granitos alcalinos da ZCRP, os valores de $\mathrm{T}_{\text {liquidus }}$ são equivalentes e variam entre $885 \pm 7^{\circ} \mathrm{C}$ (Japi) e $892 \pm 24^{\circ} \mathrm{C}$ (Caxexa, Serra do Algodão/Boqueirão). Os valores estão de acordo com as temperaturas entre 800 e $900^{\circ} \mathrm{C}$ comumente encontradas em granitos de tipo-A(Clemens et al., 1986; Patiño-Douce, 1997;
King et al., 1997, 2001; Guimarães et al., 2004; Cunha et al., 2016). Os valores mais altos nos plútons Serra Negra do Norte, Japi, Caxexa e Serra do Algodão/Boqueirão estão ainda de acordo com a presença de clinopiroxênio nesses corpos.

As temperaturas de saturação de apatita (Tsat ${ }_{a p}$ ), calculadas de acordo com Harrison e Watson (1984), são mais altas que as Tsat ${ }_{\mathrm{zr}}$ em todos os plútons, variando entre $841-891^{\circ} \mathrm{C}$, de acordo com o caráter precoce desse mineral. Já as TzrMelts

Tabela 4. Estimativas geotermométricas $\left({ }^{\circ} \mathrm{C}\right)$ médias e desvios padrão associados para os granitos alcalinos dos Domínios Rio Piranhas-Seridó e São José do Campestre, Província Borborema. São também listadas para comparação as estimativas para granitos tipo-A da Zona Transversal (Terrenos Alto Moxotó/Alto Pajeú e Piancó-Alto Brígida). Plútons: Serra do Algodão (SA); Serra do Boqueirão (SB); Olho D’Água (OD). Abreviações dos geotermômetros conforme Tabela 2.

\begin{tabular}{|c|c|c|c|c|c|c|}
\hline $\begin{array}{l}\text { Geotermômetros } \\
\mathrm{T}\left({ }^{\circ} \mathrm{C}\right) \text { mínima - máxima } \\
T\left({ }^{\circ} \mathrm{C}\right) \text { média } \pm \text { desvio padrão } \\
\text { número de amostras/análises }\end{array}$ & $\begin{array}{l}\text { Serra Negra } \\
\text { do Norte }\end{array}$ & Flores & Japi & $\begin{array}{c}\text { Caxexa, } \\
\text { SA, SB, OD }\end{array}$ & PAB & AMT/APT \\
\hline $\mathrm{T}_{\text {liquidus }}$ & $\begin{array}{c}868-915 \\
892 \pm 24 \\
N=2\end{array}$ & $\begin{array}{c}816-820 \\
818 \pm 2 \\
N=2\end{array}$ & $\begin{array}{c}878-892 \\
885 \pm 7 \\
N=2\end{array}$ & $\begin{array}{c}893-940 \\
917 \pm 24 \\
N=2\end{array}$ & - & - \\
\hline TSat $_{A P}$ & $\begin{array}{c}800-983 \\
891 \pm 57 \\
N=21\end{array}$ & $\begin{array}{c}797-983 \\
845 \pm 33 \\
N=15\end{array}$ & $\begin{array}{c}781-903 \\
845 \pm 36 \\
N=18\end{array}$ & $\begin{array}{c}731-937 \\
841 \pm 46 \\
N=35 \\
774-849\end{array}$ & $\begin{array}{c}803-987 \\
887 \pm 45 \\
N=25\end{array}$ & $\begin{array}{c}786-996 \\
913 \pm 53 \\
N=51\end{array}$ \\
\hline TCpx P08 & - & - & - & $\begin{array}{c}819 \pm 35 \\
N=15\end{array}$ & - & - \\
\hline TCpxMelts & - & - & $\begin{array}{c}789-837 \\
813 \pm 24 \\
N=2\end{array}$ & $\begin{array}{c}806-838 \\
822 \pm 16 \\
N=2\end{array}$ & - & - \\
\hline TzrMelts & $\begin{array}{c}832-834 \\
833 \pm 1 \\
N=2\end{array}$ & $\begin{array}{c}786-800 \\
793 \pm 7 \\
N=2\end{array}$ & $\begin{array}{c}782-784 \\
783 \pm 1 \\
N=2\end{array}$ & $\begin{array}{l}811-821 \\
816 \pm 5 \\
N=2\end{array}$ & - & - \\
\hline Tsat $_{z r}$ & $\begin{array}{c}768-895 \\
812 \pm 33 \\
N=21\end{array}$ & $\begin{array}{c}709-840 \\
793 \pm 42 \\
N=15\end{array}$ & $\begin{array}{c}704-820 \\
748 \pm 29 \\
N=18\end{array}$ & $\begin{array}{c}668-785 \\
736 \pm 45 \\
N=24 \\
770-820\end{array}$ & $\begin{array}{c}685-842 \\
751 \pm 38 \\
N=23\end{array}$ & $\begin{array}{c}752-969 \\
870 \pm 51 \\
N=47\end{array}$ \\
\hline $\mathrm{TZr} r_{\mathrm{ttn}}$ & - & - & - & $\begin{array}{c}777 \pm 39 \\
N=4\end{array}$ & - & - \\
\hline THblMelts & - & - & $\begin{array}{c}724-742 \\
733 \pm 9 \\
N=2\end{array}$ & - & - & - \\
\hline TBtMelts & $\begin{array}{c}783-795 \\
789 \pm 6 \\
N=2\end{array}$ & $\begin{array}{c}745-755 \\
750 \pm 5 \\
N=2\end{array}$ & - & - & - & - \\
\hline THbl R2010 & $\begin{array}{c}704-860 \\
751 \pm 40 \\
N=17\end{array}$ & - & $\begin{array}{c}715-751 \\
728 \pm 16 \\
N=2\end{array}$ & - & - & $\begin{array}{c}787-908 \\
849 \pm 35 \\
N=28\end{array}$ \\
\hline T Qz-Ab-Or & $\begin{array}{c}660-710 \\
685 \pm 25 \\
N=11\end{array}$ & $\begin{array}{c}680-700 \\
690 \pm 10 \\
N=9\end{array}$ & $\begin{array}{c}660-700 \\
680 \pm 20 \\
N=5\end{array}$ & $\begin{array}{c}660-710 \\
685 \pm 25 \\
N=7\end{array}$ & - & - \\
\hline $\mathrm{T}_{\text {solidus }}$ & $\begin{array}{c}655-663 \\
659 \pm 4 \\
N=2\end{array}$ & $\begin{array}{c}666-670 \\
668 \pm 2 \\
N=2\end{array}$ & $\begin{array}{c}690-694 \\
692 \pm 2 \\
N=2\end{array}$ & $\begin{array}{c}681-713 \\
697 \pm 16 \\
N=2\end{array}$ & - & - \\
\hline
\end{tabular}

AMT/APT: Terrenos Alto Moxotó/Alto Pajeú; PAB: Terreno Piancó-Alto Brígida. 
modeladas (Figura 7) são mais altas nos plútons Serra Negra do Norte $\left(833 \pm 1^{\circ} \mathrm{C}\right)$ e Caxexa/Serra do Algodão/Boqueirão/ Olho D'Água $\left(816 \pm 5^{\circ} \mathrm{C}\right)$, e variam entre $783 \pm 1^{\circ} \mathrm{C}$ e $793 \pm$ $7^{\circ} \mathrm{C}$ no plúton Japi e stock Flores, respectivamente.

As TzrMelts para o plúton Serra Negra do Norte são mais precisas e adequadas em comparação ao largo intervalo de Tsat ${ }_{\mathrm{zr}}$ entre 750 e $930^{\circ} \mathrm{C}$ interpretado por Campos et al. (2000) como as $\mathrm{T}_{\text {liquidus }}$ desse corpo. Cabe destacar que os valores anomalamente altos de $\mathrm{Zr}$ para amostras desse plúton são associados à presença de cumulatos de zircão (Campos et al., 2000) e destoam do conjunto de dados (Figura 8). Dessa forma, o valor médio de Tsat ${ }_{\text {zr }}$ reportado na Tabela 4 $\left(812 \pm 23^{\circ} \mathrm{C}\right)$, calculado segundo Watson e Harrison (1983), desconsidera amostras com $\mathrm{Zr}>\sim 400 \mathrm{ppm}$ (Figura 8).

Nos plútons Japi, Caxexa/Serra do Algodão/Boqueirão/ Olho D'Água, os valores modelados de TzrMelts (Figura 7) são mais altos do que aqueles calculados de acordo com Watson e Harrison (1983), estes com médias de $748 \pm$ $29^{\circ} \mathrm{C}$ (Japi), $743 \pm 29^{\circ} \mathrm{C}$ (Caxexa) e $726 \pm 59^{\circ} \mathrm{C}$ (Serra do Algodão/Boqueirão/Olho D'Água) (Tabela 4; ver também Nascimento, 2000; Nascimento et al., 2010). Tsat ${ }_{z \mathrm{r}}$ baixas como essas estão associadas a baixos teores de $\mathrm{Zr}$ em rocha-total (Figura 8) e poderiam induzir a classificação desses plútons como típicos "granitos frios" (Chappell et al., 1998; Miller et al., 2003). Tal classificação é questionada por Siégel et al. (2018) por assumir $\mathrm{Tsat}_{\mathrm{zr}}=\mathrm{T}_{\text {liquidus }}$. Além disso, esses valores estão em desacordo com as temperaturas associadas à formação de granitos alcalinos, em geral $>800^{\circ} \mathrm{C}$, tal como observado anteriormente. Como alternativa, baixas Tsat ${ }_{\mathrm{zr}}$ podem estar associadas à cristalização a partir de um magma inicialmente subsaturado em zircão. De fato, embora o plúton Japi mostre diminuição de $\mathrm{Zr}$ em direção a composições mais evoluídas, isso não se visualiza de forma convincente para os plútons Caxexa, Serra do Algodão/Boqueirão e Olho D'Água (Figura 8B). Tal interpretação é suportada por cálculos com o modelo de Watson e Harrison (1983) assumindo a temperatura mínima de $800^{\circ} \mathrm{C}$ para $\mathrm{T}_{\text {liquidus }}$ desses granitos (Clemens et al., 1986). Nesse caso, o conteúdo mínimo de $\mathrm{Zr}$ necessário para a cristalização do zircão seria $\sim 200 \mathrm{ppm}$, bem acima dos valores médios encontrados (90-118 ppm). Adicionalmente, Villaseca et al. (2007) demonstraram que a fusão parcial de rochas granulíticas pode dar origem a magmas graníticos com baixos teores de $\mathrm{Zr}$.

Nos plútons Japi e Caxexa/Serra do Algodão/Boqueirão, as simulações com o rhyolite-MELTS indicam temperaturas de

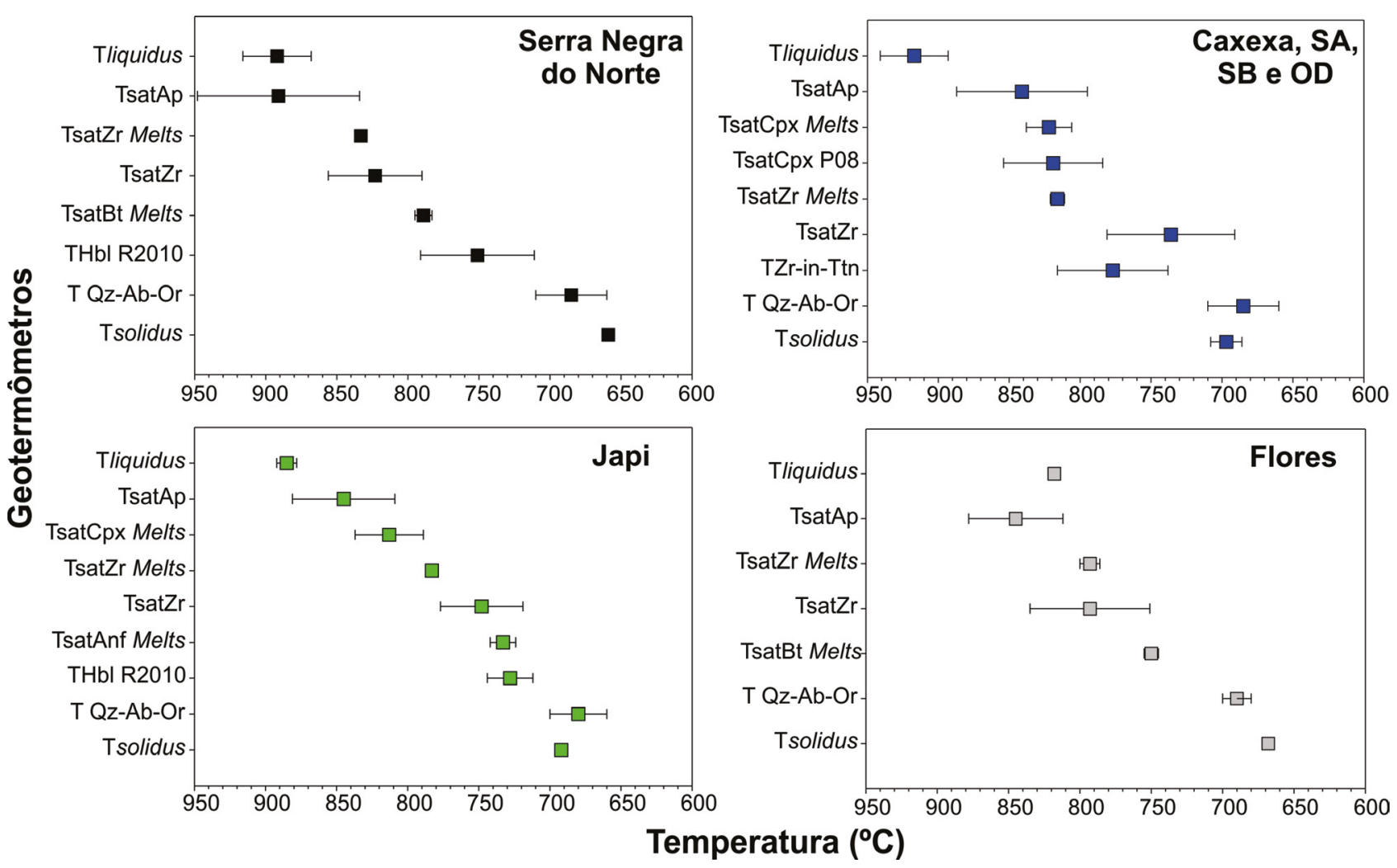

Figura 7. Diagramas ilustrando o intervalo de cristalização $(\Delta T)$ dos plútons alcalinos dos Domínios Rio Piranhas-Seridó (RPS) e São José do Campestre (SJC), Província Borborema, a partir das estimativas termométricas obtidas na Tabela 4. Abreviação dos geotermômetros conforme Tabela 2. Plútons: Serra do Algodão (SA); Serra do Boqueirão (SB); Olho D’Água (OD). 
cristalização para o clinopiroxênio entre $813 \pm 24^{\circ} \mathrm{C}$ (Japi) e $822 \pm 16^{\circ} \mathrm{C}$ (Caxexa/Serra do Algodão/Boqueirão). No último caso, uma estimativa similar de $819 \pm 35^{\circ} \mathrm{C}$ é obtida a partir do equilíbrio clinopiroxênio-líquido (Putirka, 2008). No plúton Japi, o clinopiroxênio dá lugar a anfibólio em $733 \pm$ $9^{\circ} \mathrm{C}$, temperatura similar a obtida com o geotermômetro de Ridolfi et al. (2010) de $728 \pm 16^{\circ} \mathrm{C}$.

Para o plúton Caxexa, a temperatura de cristalização da titanita foi obtida com o uso do geotermômetro Zr-emtitanita de Hayden et al. (2008) a partir dos teores de $\mathrm{Zr}$ via laser ablation (Tabela 5). Esse geotermômetro considera a $a \mathrm{SiO}_{2}$ e $a \mathrm{TiO}_{2}$ no momento da cristalização da titanita, de acordo com a Equação 3:

$\mathrm{T}\left({ }^{\circ} \mathrm{C}\right)=[7708+960 \mathrm{P}] /\left[10,52-\log \left(a \mathrm{SiO}_{2}\right)\right.$

$\left.-\log \left(a \mathrm{TiO}_{2}\right)-\log \left(\mathrm{Zr}_{\mathrm{ttn}}\right)\right]-273$

Em que:

$\mathrm{P}=$ pressão $(\mathrm{GPa})$;

$\mathrm{Zr}_{\text {ttn }}=$ teor de $\mathrm{Zr}(\mathrm{ppm})$ na titanita.

Dada a natureza supersaturada das rochas do plúton Caxexa, a $a \mathrm{SiO}_{2}$ foi fixada em 1,0. Para $a \mathrm{TiO}_{2}$, adotou-se um valor de 0,7 , de acordo com Claiborne et al. (2010). A pressão utilizada foi de 3,6 kbar (Tabela 3). As temperaturas obtidas $\left(\mathrm{TZr}_{\text {ttn }}\right)$ variam entre $719 \mathrm{e} 830^{\circ} \mathrm{C}$, com média de $777 \pm 39^{\circ} \mathrm{C}$. A sobreposição desses valores com as temperaturas de cristalização do clinopiroxênio são confirmadas pela ocorrência de pequenas inclusões de titanita em cristais de clinopiroxênio no plúton Caxexa.

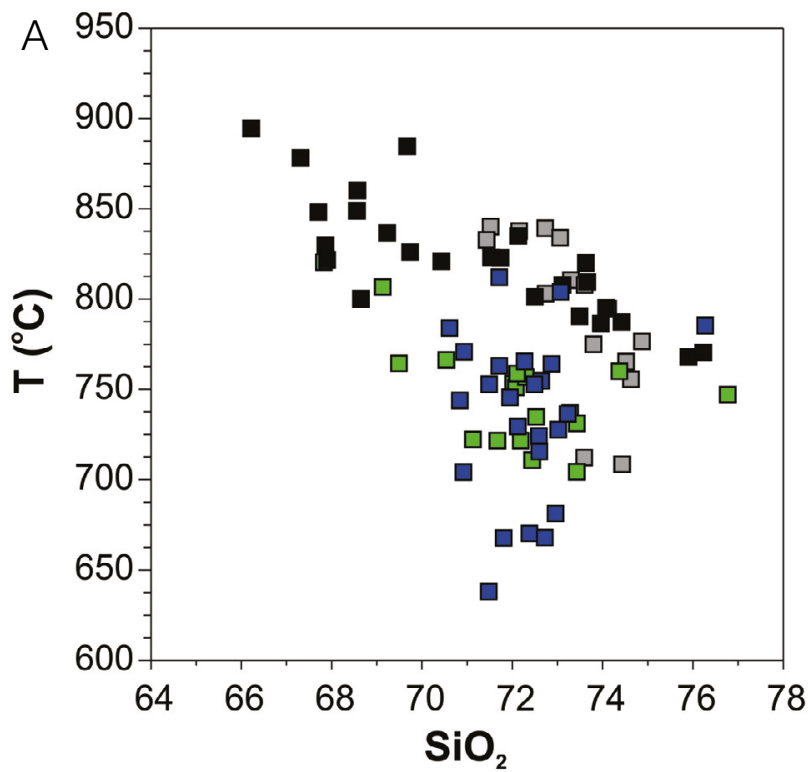

Para o plúton Serra Negra do Norte e o stock Flores, as temperaturas de cristalização de hornblenda (somente no Serra Negra do Norte) e biotita foram estimadas com o geotermômetro de Ridolfi et al. (2010) e com o rhyolite-MELTS, respectivamente. As simulações para o plúton Serra Negra do Norte não precipitaram o anfibólio. Os resultados indicam temperaturas de $751 \pm 40^{\circ} \mathrm{C}$ para a hornblenda, e entre $789 \pm 6^{\circ} \mathrm{C}$ e $750 \pm 5^{\circ} \mathrm{C}$ para a biotita do plúton Serra Negra do Norte e stock Flores, respectivamente. Os cálculos com o geotermômetro de Ridolfi et al. (2010) não incluíram análises referentes a actinolita, interpretadas como de formação tardi- a pós-magmática (Campos et al., 2000). Estas resultam em temperaturas em torno de $705 \pm 16^{\circ} \mathrm{C}$, próximas às estimativas de $\mathrm{T}_{\text {solidus }}$ (Figura 7). Outrossim, a sobreposição das temperaturas, com valores em média mais altos para a biotita, encontra respaldo petrográfico no plúton Serra

Tabela 5. Temperaturas de cristalização de titanita no plúton Caxexa obtidas pelo geotermômetro Zr-emtitanita $\left(\mathrm{TZr}_{\mathrm{ttn}}\right)$ a partir dos teores de $\mathrm{Zr}(\mathrm{ppm})$ medidos via técnica analítica de ablação a laser associada com um espectrômetro de massas com plasma indutivamente acoplado (LA-ICP-MS). $2 \sigma$ representa o erro associado a cada análise.

\begin{tabular}{lcccc}
\hline Cristal & ttn-1 & ttn-2 & ttn-3 & ttn-4 \\
\hline $\operatorname{Zr}(\mathrm{pppm})$ & 2.373 & 1.049 & 1.049 & 360 \\
$2 \sigma$ & 294 & 131 & 141 & 45 \\
$\mathrm{~T}\left({ }^{\circ} \mathrm{C}\right)$ & 830 & 779 & 779 & 719 \\
$\mathrm{TZr} r_{\text {tn }}\left({ }^{\circ} \mathrm{C}\right)$ média & \multicolumn{4}{c}{$777 \pm 39$} \\
\hline
\end{tabular}

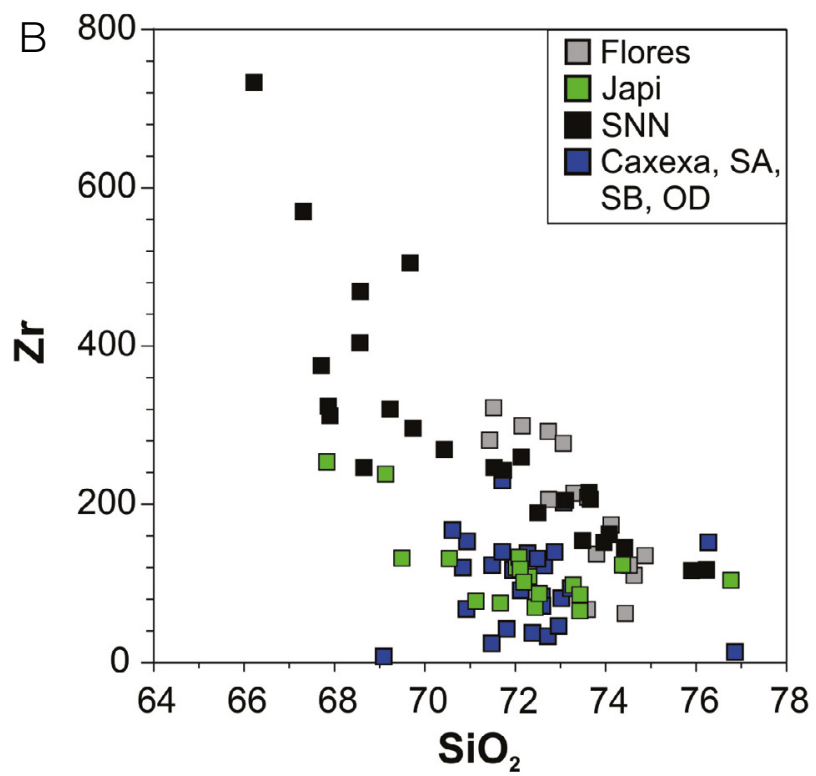

Figura 8. Diagramas binários de variação das temperaturas de saturação de zircão (Tsat plútons alcalinos dos Domínios Rio Piranhas-Seridó (RPS) e São José do Campestre (SJC), Província Borborema. (A) Diagrama Tsat ${ }_{\mathrm{zr}}$ versus $\mathrm{SiO}_{2}$ (\% em peso) em rocha-total. (B) Diagrama $\mathrm{Zr}$ (ppm) versus $\mathrm{SiO}_{2}$ (\% em peso) em rocha-total. Plútons: Serra do Algodão (SA), Serra do Boqueirão (SB), Olho D’Água (OD), Serra Negra do Norte (SNN). 
Negra do Norte, uma vez que é comum nos litotipos desse plúton a presença de inclusões de biotita em hornblenda e intercrescimento entre essas fases (Campos et al., 2000).

Cabe registrar que a composição mais sódica do plagioclásio (albita a oligoclásio sódico; $\mathrm{An}<19 \%$ ) e a presença de hornblenda com razão fe\# $(\mathrm{Fe} / \mathrm{Fe}+\mathrm{Mg})<0,4$ no Serra Negra do Norte impede rigorosamente a aplicação do geotermômetro hornblenda-plagioclásio (Holland e Blundy, 1994; Anderson e Smith, 1995). Apesar disso, Campos et al. (2000) apresentam temperaturas entre 725 e $782^{\circ} \mathrm{C}$, obtidas com esse geotermômetro, que se sobrepõem às nossas estimativas.

As temperaturas finais de cristalização $\left(\mathrm{T}_{\text {solidus }}\right)$ foram obtidas de duas formas:

- a partir do sistema isobárico quartzo (Qz) - albita $(\mathrm{Ab})$ - ortoclásio (Or) (sistema haplogranítico) para $3 \mathrm{kbar}$ (Tuttle e Bowen, 1958), 4 kbar (Steiner et al., 1975) e 5 kbar (Luth et al., 1964);

- a partir das simulações no rhyolite-MELTS. Os resultados são equivalentes e indicam $\mathrm{T}_{\text {solidus }}$ entre 660 e $700^{\circ} \mathrm{C}$; os menores valores $\left(\sim 660-670^{\circ} \mathrm{C}\right)$ registrados para o plúton Serra Negra do Norte e stock Flores. No último caso, os valores mais baixos podem estar associados a um excesso de flúor no magma (Manning, 1981), tal como atesta a presença de fluorita nesse corpo (Souza et al., 2017).

Conclui-se, portanto, um intervalo de cristalização $\left(\Delta \mathrm{T}_{\text {cristal }}\right)$ para os granitos alcalinos dos Domínios RPS e SJC entre 150 e $233^{\circ} \mathrm{C}$, com o stock Flores representando a intrusão (de menores dimensões) mais rasa (3,0 kbar) e de menor $\Delta \mathrm{T}_{\text {cristal }}$

\section{Fugacidade de oxigênio}

Inferências disponíveis na literatura sobre as condições de fugacidade de oxigênio $\left(f \mathrm{O}_{2}\right)$ durante a cristalização dos granitos em questão são baseadas principalmente em evidências petrográficas. Em linhas gerais, a ocorrência comum da paragênese titanita + magnetita + quartzo em equilíbrio (Wones, 1989), alinhada com anomalias de Eu em rocha-total positivas a levemente positivas (plútons Caxexa, Serra do Algodão/ Boqueirão, Serra Negra do Norte e Japi) apontam para um ambiente de cristalização relativamente oxidado (Campos et al., 2000; Nascimento et al., 2003; Nascimento et al., 2010).

Para o plúton Caxexa é possível quantificar a $\mathrm{fO}_{2}$ a partir da relação de substituição entre clinopiroxênio (hedenbergita) e granada (andradita) existente nesse corpo (Gustafson, 1974; Nascimento et al., 2003; Dalan et al., 2017). Durante estágios tardi-magmáticos, em meio oxidante, andradita e óxido de ferro se formam a partir da desestabilização da hedenbergita através da reação expressa pela Equação 4 (Zhang e Saxena, 1991):

$$
\begin{aligned}
& 9 / 2 \mathrm{CaFeSi}_{2} \mathrm{O}_{6}+\mathrm{O}_{2} \leftrightarrow 3 / 2 \mathrm{Ca}_{3} \mathrm{Fe}_{2} \mathrm{Si}_{3} \mathrm{O}_{12}+1 / 2 \mathrm{Fe}_{3} \mathrm{O}_{4}+9 / 2 \mathrm{SiO}_{2}(4) \\
& \text { Hedenbergita andradita magnetita quartzo. }
\end{aligned}
$$

As propriedades termodinâmicas dessa reação são apresentadas por Zhang e Saxena (1991), o que permite seu uso para estimativas quantitativas de $f \mathrm{O}_{2}$, uma vez que se conheçam as composições da hedenbergita e andradita, temperatura e pressão de cristalização, por meio da Equação 5:

$\left.\log _{\mathrm{fO} 2}=12,51+\mathrm{A}+\mathrm{B} / \mathrm{T}\left({ }^{\circ} \mathrm{K}\right)+0,078[\mathrm{P}(\mathrm{kbar})-1) / \mathrm{T}\left({ }^{\circ} \mathrm{K}\right)\right](5)$

Em que:

$\mathrm{A}=3 \log \mathrm{X}_{\mathrm{ad}}-4,5 \log \mathrm{X}_{\mathrm{hd}}(\mathrm{ad}=$ moléc. andradita; $\mathrm{hd}=$ molécula de hedenbergita);

$\mathrm{B}=-27.576-1.007\left(1-\mathrm{X}_{\mathrm{ad}}\right)^{2}-1.476\left(1-\mathrm{X}_{\mathrm{hd}}\right)^{2}$

Foram utilizados dados químicos de cristais de hedenbergita e andradita em reação do plúton Caxexa, obtidas por Nascimento (2000), para a pressão de 3,6 kbar e temperatura de quasi-solidus média de $685^{\circ} \mathrm{C}$. Os valores de $\log _{\mathrm{fO} 2}$ obtidos variam entre $-15,6$ e $-15,8$ e atestam a cristalização sob condições oxidantes, pouco acima do tampão QFM $\left(+1,2<\Delta_{\mathrm{OFM}}<+1,4\right)$. Ademais, Nascimento (1998) descreve hematita bordejada por titanita nos plútons Serra do Algodão/Boqueirão, o que sugere que nesses casos as condições se tornaram ainda mais oxidantes.

Anderson e Smith (1995) e Anderson et al. (2008) correlacionam as condições redox de cristalização de um magma com valores do índice fe\# $[\mathrm{Fe} /(\mathrm{Fe}+\mathrm{Mg})]$ em hornblenda e biotita. De fato, com o aumento da $f \mathrm{O}_{2}$ durante a cristalização, hornblenda e biotita tornam-se progressivamente mais magnesianas (Wones, 1989), uma vez que a entrada de $\mathrm{Fe}^{3+}$ no lugar de $\mathrm{Al}$ na estrutura desses minerais é favorecida no lugar de $\mathrm{Fe}^{2+}$. Dessa forma, anfibólio e/ou biotita com razões fe\# elevadas são interpretados como formados sob baixas $\mathrm{fO}_{2}$ (Hollister et al., 1987; Anderson e Smith, 1995; Anderson, 1996). Os diagramas da Figura 9 mostram que as razões fe\# desses minerais nos plútons Serra Negra do Norte e Japi (somente anfibólio) são compatíveis com $f \mathrm{O}_{2}$ mais elevadas $\left(\Delta_{\mathrm{OFM}} \approx+1,5 \mathrm{a}+2,5\right)$ similares às encontradas nos granitos da "série-magnetita" de Anderson et al. (2008). Tais condições são distintas das verificadas para os granitos de tipo-A aflorantes nos terrenos AMT/APT da Zona Transversal, cujas razões fe\# em anfibólio e biotita indicam $\mathrm{fO}_{2}$ intermediárias a baixas (Figura 9).

Estimativas quantitativas da $f \mathrm{O}_{2}$ para os plútons Serra Negra do Norte e Japi foram obtidas a partir da composição do anfibólio com o oxibarômetro de Ridolfi et al. (2010). Os resultados (Figura 10) indicam condições progressivamente mais oxidantes com o decorrer da cristalização e sempre maiores do que aquelas nos granitos tipo-A da Zona Transversal, com $\log _{\mathrm{fO} 2}$ entre $-14,2$ e $-14,5$ para o Japi $(+1,0$ $\left.<\Delta_{\mathrm{OFM}}<+1,5\right)$, e entre $-13,1$ e $-14,8$ para o Serra Negra do Norte $\left(+1,7<\Delta_{\mathrm{OFM}}<+2,1\right)$. Nesse último caso, os valores indicam condições levemente mais oxidantes daquelas 
propostas por Campos et al. (2000) e são coerentes com a presença de epidoto magmático (Sial et al., 2008).

O stock Flores também apresenta a paragênese titanita + magnetita + quartzo (em equilíbrio), o que levou Souza et al. (2017) a interpretá-lo como um granito de tipo-A oxidado (Dall'Agnol e Oliveira, 2007). Contudo, as rochas desse stock possuem biotita com razões fe\# mais altas $(\sim 0,8)$, similares às encontradas nos granitos de tipo-A dos terrenos AMT/APT (Figura 9B). Essa observação, aliada às anomalias negativas de Eu observadas em rocha-total (Souza et al., 2017), aponta para $f \mathrm{O}_{2}$ mais baixas durante a cristalização, em comparação aos demais plútons estudados e a típicos granitos de tipo-A oxidados (Rämö et al., 2002; Dall'Agnol e Oliveira, 2007), ao longo ou levemente acima do tampão QFM $\left(\log _{f \mathrm{O} 2} \sim 15,5\right.$ para $\left.750^{\circ} \mathrm{C}\right)$. Sob tais condições, a cristalização de magnetita é possível e o magma permanece reduzido, o que explica os valores elevados de fe\# na biotita e em rocha-total (Souza et al., 2017). Dall'Agnol e Oliveira (2007) apontam que condições próximas ao tampão NNO, tais como observadas para os demais plútons estudados, definem as $f \mathrm{O}_{2}$ mínimas para a formação de granitos de tipo-A oxidados, de forma que aqueles portando magnetita formados próximos ao tampão QFM não são estritamente oxidados. Em outras palavras, a presença de magnetita em granitos não é incompatível com um caráter mais reduzido de seus magmas parentais (Anderson e Smith, 1995; Dall'Agnol e Oliveira, 2007; Anderson et al., 2008; Cunha et al., 2016; Campos et al., 2016).

\section{Implicações geodinâmicas}

A suíte granítica alcalina, tal como definida por Nascimento et al. (2015), faz parte do intenso magmatismo que marca os

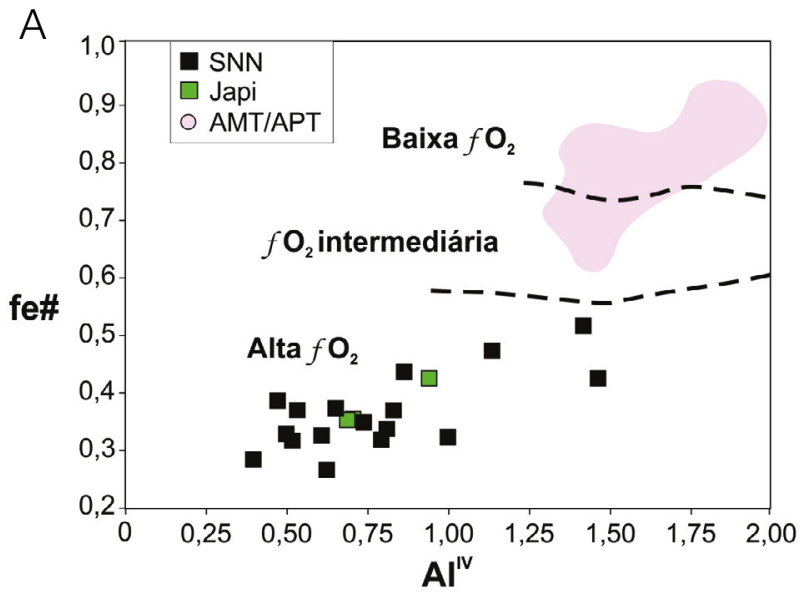

domínios tectonoestruturais RPS e SJC, no extremo NE da Província Borborema, entre o final do período ediacarano e começo do cambriano. Além da suíte alcalina, esse magmatismo engloba granitos cálcio-alcalinos de alto $\mathrm{K}$ que formam intrusões de dimensões batolíticas em ambos os domínios. Esses corpos são quimicamente similares, e suas condições de cristalização foram estudadas por Campos et al. (2016), que estimaram pressões de colocação entre 4,2-5,4 kbar e 4,9-5,6 kbar e para os corpos intrusivos nos Domínios

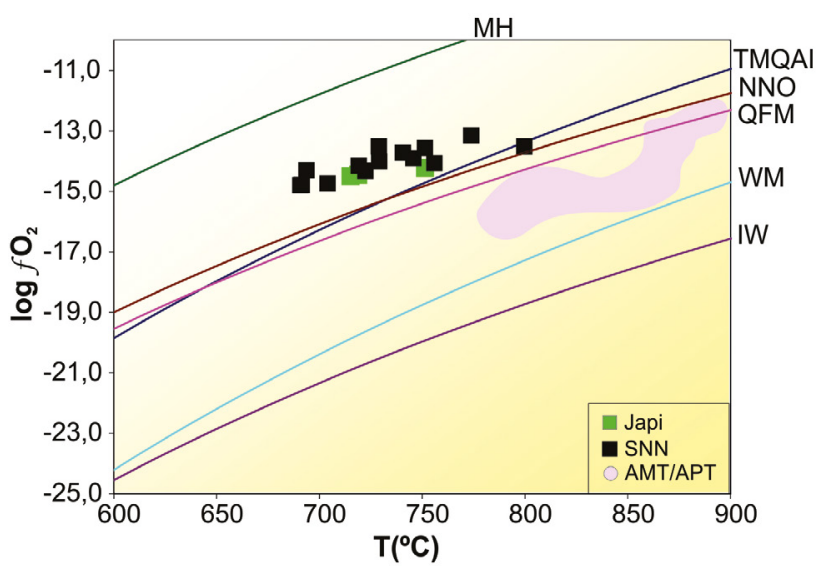

SNN: Plúton Serra Negra do Norte; AMT/APT: granitos tipo-A dos Terrenos Alto Moxotó/Alto Pajeú (Zona Transversal).

Figura 10. Diagrama binário temperatura $\left({ }^{\circ} \mathrm{C}\right)$ versus $\log \mathrm{fO}_{2}$ para os plútons Japi e Serra Negra do Norte e granitos tipo-A da Zona Transversal. Temperaturas e fugacidades de oxigênio calculadas a partir da composição do anfibólio de acordo com Ridolfi et al. (2010). Tampões (para 3,0 kbar): ferro-wüstita (IW), wüstita-magnetita (WM), quartzofaialita-magnetita (QFM), níquel-bunsenita (NNO), titanitamagnetita-quartzo-anfibólio-ilmenita (TMQAI), magnetitahematita $(\mathrm{MH})$.

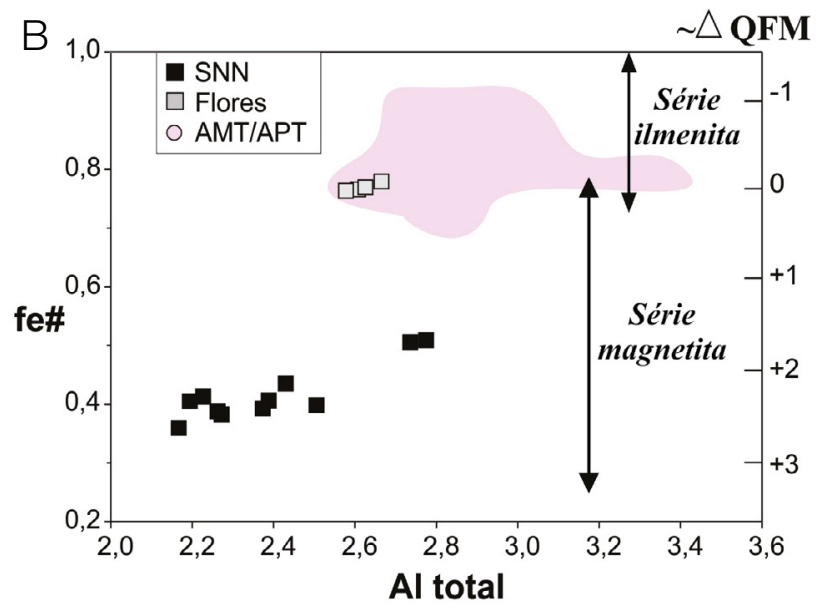

SNN: Plúton Serra Negra do Norte; AMT/APT: granitos tipo-A dos Terrenos Alto Moxotó/Alto Pajeú (Zona Transversal).

Figura 9. Estimativas das condições redox de cristalização dos plútons Serra Negra do Norte, Flores e Japi a partir da composição de anfibólio e biotita. (A) Diagrama catiônico Alv versus fe\# (Fe/Fe + Mg) para o anfibólio com os campos de diferentes $\mathrm{fO}_{2}$ de acordo com Anderson e Smith (1995). (B) Diagrama catiônico Al total versus fe\# de Anderson et al. (2008) para a biotita, com $\mathrm{fO}_{2}$ dada em relação ao tampão quartzo-faialita-magnetita (QFM) comparada a granitos da série ilmenita e magnetita mesoproterozoicos da Laurentia (Anderson et al., 2008). 
SJC e RPS, respectivamente. As pressões calculadas para os granitos da suíte alcalina são, em geral, inferiores, entre 3,0-3,7 kbar, à exceção do plúton Japi, colocado sob pressões de 5,3 kbar equivalentes aos corpos cálcio-alcalinos. Por outro lado, as estimativas de $\mathrm{T}_{\text {liquidus }}$ são maiores, o que está de acordo com dados experimentais que mostram que granitos de tipo-A se formam em temperaturas em geral mais altas que granitos cálcio-alcalinos (Clemens et al., 1986; Patiño-Douce, 1997). Assumindo-se uma densidade média da crosta de $2,65 \mathrm{~g} / \mathrm{cm}^{3}$, essas pressões indicam profundidades de colocação entre 14-20 km e 12-14 km para os plútons nos domínios SJC (Japi, Caxexa, Serra do Algodão, Serra do Boqueirão e Olho D'Água) e RPS (Serra Negra do Norte e Flores), respectivamente (Figura 11).

Os diferentes níveis crustais de alojamento entre os dois domínios são também acompanhados por um contraste químico entre os corpos: entre outras particularidades, aqueles intrusivos no Domínio SJC apresentam maiores teores de álcalis totais, o que acaba se refletindo em sua mineralogia (e.g., egirina-augita). Tais diferenças podem estar associadas a áreas-fontes distintas (mais anidras para os plútons no Domínio SJC), bem como ao controle estrutural do alojamento desses plútons (Jardim de Sá et al., 1999). Chama a atenção que os plútons Serra Negra do Norte e Flores (Domínio RPS) formam intrusões mais rasas não associadas com zonas de cisalhamento regionais importantes (Figura 11), correspondendo a granitos intraplaca e/ou pós-colisionais nos diagramas de ambientação tectônica de Pearce et al. (1984) e Pearce (1996) (Figura 12; ver também Campos et al., 2000; Souza et al., 2017), tal como os granitos tipo-A dos terrenos Alto Moxotó e Alto Pajeú (Domínio da Zona Transversal - ZT), dos quais compartilham também diversas características litoquímicas (especialmente o stock Flores). Por outro lado, os plútons intrusivos no Domínio SJC são mais profundos, de forma mais clara quando se considera o plúton Japi. Em comum, esses granitos têm sua colocação associada a zonas de cisalhamento regionais transcorrentes com componentes

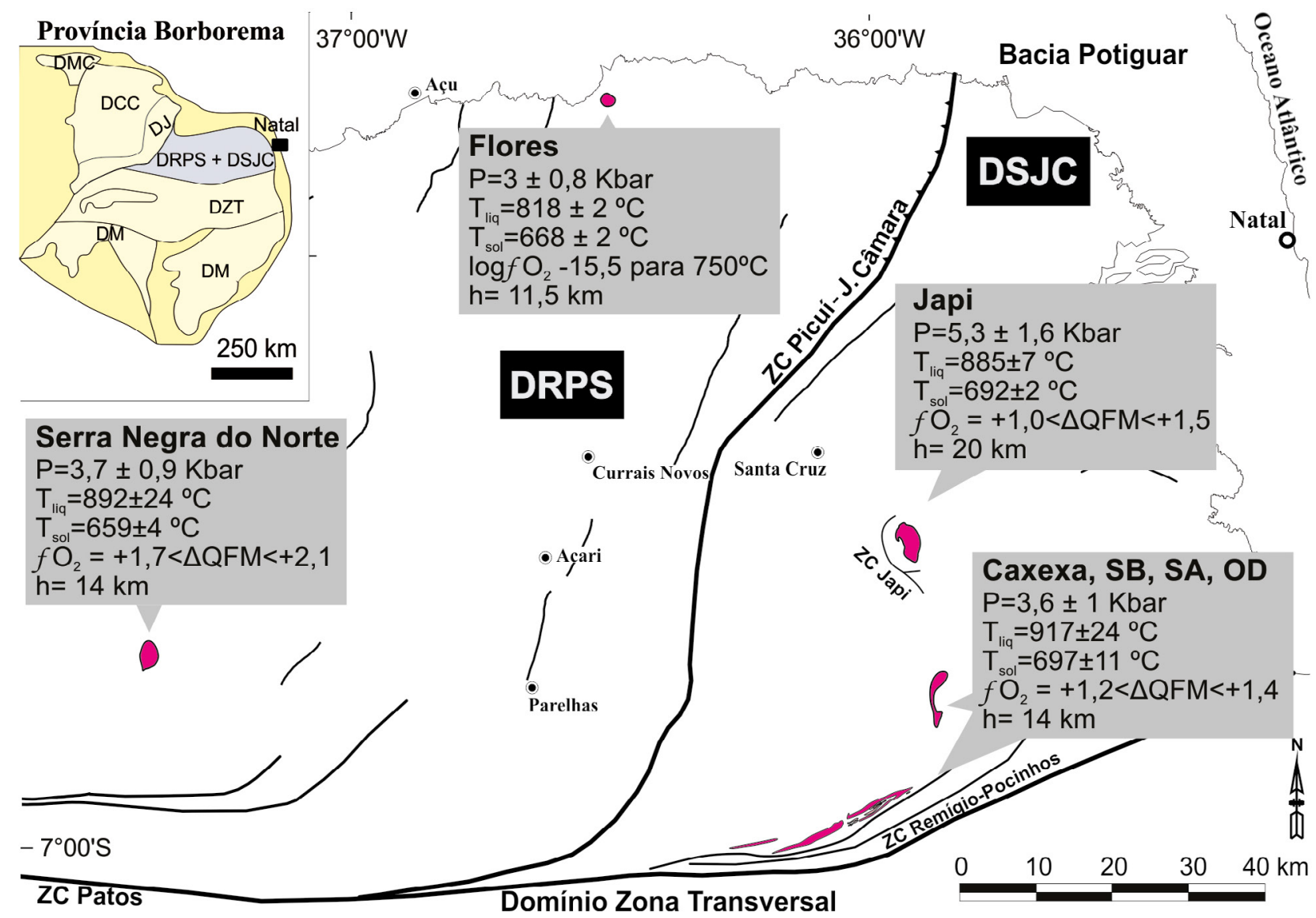

DMC: Domínio Tectonoestratigráfico Médio Coreaú; DCC: Domínio Ceará Central; DJ: Domínio Jaguaribeano; DRPS: Domínio Rio Piranhas-Seridó; DZT: Domínio Zona Transversal; DM: Domínio Meridional; QFM: quartzo-faialita-magnetita; ZC: zona de cisalhamento; SB: Serra do Boqueirão; SA: Serra do Algodão; OD: Olho D’Água; DRPS: Domínio Rio Piranhas-Seridó; DSJC: Domínio São José do Campestre.

Figura 11. Esquema geológico do extremo NE da Província Borborema mostrando a localização dos plútons estudados com as respectivas pressões médias $(P)$, temperaturas de liquidus $\left(\mathrm{T}_{\text {liq }}\right)$ e solidus $\left(\mathrm{T}_{\text {sol }}\right)$, fugacidade de oxigênio $\left(f \mathrm{O}_{2}\right)$ e profundidade de alojamento (h). 
distensionais (Jardim de Sá et al., 1999; Hollanda et al., 1999): as zonas de cisalhamento Japi (plúton Japi) e Remígio-Pocinhos (plútons Caxexa, Serra do Algodão, Serra do Boqueirão e Olho D'Água) (Figura 11). Essas zonas de cisalhamento podem ter dimensões litosféricas, permitindo o alojamento de magmas graníticos alcalinos de mais alta temperatura (Black et al., 1985) e rochas básicas associadas (como é o caso do plúton Japi) em níveis crustais ora mais rasos (Caxexa, Serra do Algodão/Boqueirão, Olho D’Água), ora mais profundos (Japi). Não por acaso esses plútons mostram assinatura compatível com granitos sin-colisionais e de arco magmático nos diagramas da Figura 12, como o plúton peralcalino Catingueira e corpos menores associados, alojados ao longo do Lineamento Patos (Figura 11) no Terreno Piancó-Alto Brígida (PAB; Figura 12) da Zona Transversal.

\section{CONCLUSÕES}

O estudo comparativo e a reavaliação das condições de cristalização dos granitos de afinidade alcalina (tipo-A) intrusivos nos Domínios SJC e RPS, no extremo NE da Província Borborema, permitiram as seguintes conclusões:

- A suíte granítica alcalina engloba os plútons Japi, Caxexa, Serra do Algodão, Serra do Boqueirão e Olho D’Água no Domínio SJC; e plúton Serra Negra do Norte e stock Flores no Domínio RPS;

- Os plútons intrusivos no Domínio SJC possuem maiores teores de álcalis-totais (média de 10,3\% peso). Predominam álcali-feldspato granitos, sienitos e sienogranitos, com diopsídio, hedenbergita ou egirina-augita. Nos plútons alojados no Domínio RPS ocorrem sieno- e monzogranitos com biotita $\pm \mathrm{Mg}$-ferri-hornblenda \pm diopsídio;

- Os plútons foram cristalizados sob pressões entre 3,0 e 3,7 kbar ( 11-14 km em profundidade), à exceção do plúton Japi, com pressões médias de 5,3 kbar ( 20 km);

- As temperaturas de liquidus foram modeladas entre 885 e $917^{\circ} \mathrm{C}$, à exceção do stock Flores $\left(818^{\circ} \mathrm{C}\right)$. Já as temperaturas de solidus situam-se entre 660 e $700^{\circ} \mathrm{C}$;

- Quando presentes, clinopiroxênios, anfibólios e biotita se formam entre $813-822,728-751$ e $750-789^{\circ} \mathrm{C}$, respectivamente;

- O geotermômetro $\mathrm{Zr}$-em-titanita indica temperaturas da ordem de $780^{\circ} \mathrm{C}$ (máximas de $830^{\circ} \mathrm{C}$ ) para o plúton Caxexa;

- A cristalização ocorreu sob condições essencialmente oxidantes para a maioria dos plútons $\left(+1,0<\Delta_{\mathrm{OFM}}<+2,1\right)$, à exceção do stock Flores, formado sob condições levemente mais reduzidas $\left(\Delta_{\mathrm{OFM}} \approx 0,0\right)$;

- Os resultados reforçam o papel do controle estrutural na colocação e no contraste químico entre os granitos alcalinos dos domínios RPS e SJC.
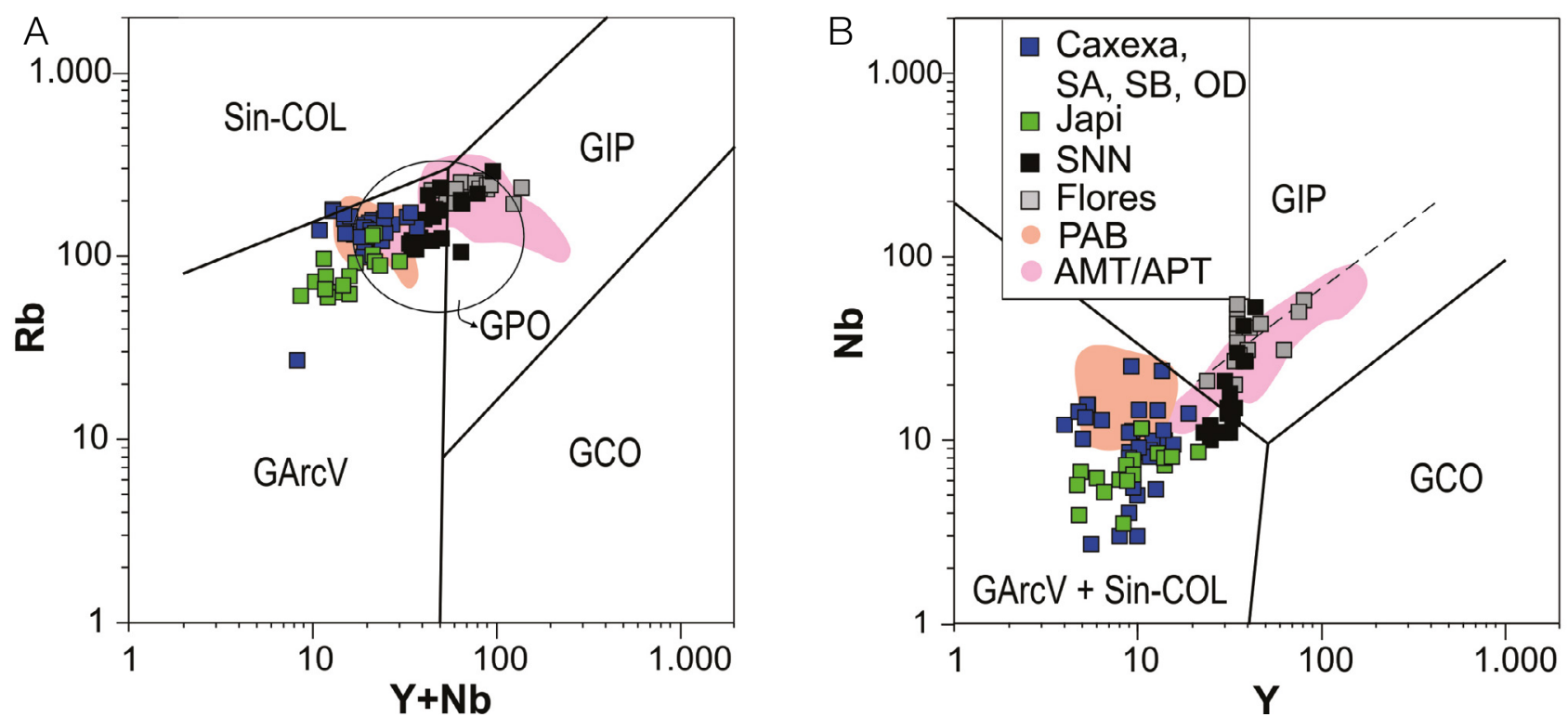

Sin-COL: granitos sin-colisionais; GArcV: Granitos de arco vulcânico; GIP: granitos intraplaca; GCO: granitos de cordilheira oceânica; GPO: granitos pós-colisionais; PAB: granitos tipo-A (peralcalinos) do Terreno Piancó-Alto Brígida (ZT); AMT/APT: granitos tipo-A (meta- a peraluminosos) dos Terrenos Alto Moxotó/Alto Pajeú (ZT).

Figura 12. Diagramas de ambientação tectônica para os granitos alcalinos dos Domínios São José do Campestre (SJC) e Rio Piranhas-Seridó (RPS) da Província Borborema. (A) Diagrama $Y+N b$ versus Rb (Pearce, 1996). (B) Diagrama $Y$ versus $\mathrm{Nb}$ (rocha-total) de Pearce et al. (1984). Os diagramas mostram também as variações dos granitos de tipo-A da Zona Transversal (Terrenos Alto Moxotó/Alto Pajeú e Piancó-Alto Brígida) para comparação regional. Plútons: Serra do Algodão (SA), Serra do Boqueirão (SB), Olho D’Água (OD) e Serra Negra do Norte (SNN). 


\section{AGRADECIMENTOS}

Os autores agradecem ao Programa de Pós-Graduação em Geodinâmica e Geofísica da UFRN, o apoio técnico e financeiro; a Thomas Ferreira da Costa Campos (UFRN), a cessão de lâminas petrográficas e dados inéditos do plúton Serra Negra do Norte; a Adriana Alves e Lucelene Martins (USP), o auxílio durante as análises de LA-ICP-MS/IGc-USP. Clarissa de Aguiar Dalan agradece à CAPES a bolsa de Mestrado recebida durante a realização deste trabalho. Os autores também agradecem aos dois revisores anônimos por seus comentários e sugestões, que contribuíram para a melhora significativa deste trabalho.

\section{REFERÊNCIAS}

Anderson, J. L. (1996). Status of thermobarometry in granitic batholiths. Earth and Environmental Science Transactions of the Royal Society of Edinburgh, 87(1-2), 125-138. https:// doi.org/10.1017/S0263593300006544

Anderson, J. L., Barth, A. P., Wooden, J. L., Mazdab, F. (2008). Thermometers and thermobarometers in granitic systems. Reviews in Mineralogy and Geochemistry, 69(1), 121-142. https://doi.org/10.2138/rmg.2008.69.4

Anderson, J. L., Smith, D. R. (1995). The effect of temperatures and oxygen fugacity on Al-in-hornblende barometry. American Mineralogist, 80(5-6), 549-559. https://doi.org/10.2138/ am-1995-5-614

Angelim, L. A. A., Nesi, J. R., Torres, H. H. F., Medeiros, V. C., Santos, C. A., Veiga Junior, J. P., Mendes, V. A. (2006). Geologia e Recursos Minerais do estado do Rio Grande do Norte: Texto Explicativo dos Mapas Geológico e de Recursos Minerais do estado do Rio Grande do Norte. Escala 1:500.000. Recife: Serviço Geológico Brasileiro (CPRM), 233 p.

Black, R., Lameyre, J., Bonin, B. (1985). The structural setting of alkaline complexes. Journal of African Earth Sciences, 3(1-2), 5-16. https://doi.org/10.1016/0899-5362(85)90019-3

Blundy, J., Cashman, K. (2001). Ascent-driven crystallisation of dacite magmas at Mount St Helens, 1980-1986. Contributions to Mineralogy and Petrology, 140(6), 631650. https://doi.org/10.1007/s004100000219

Bonin, B., Giret, A. (1984). The plutonic alkaline series: the problem of their origin and differentiation, the role of their mineralogical assemblages. Physics of the Earth and Planetary Interiors, 35(1-3), 212-221. https://doi. org/10.1016/0031-9201(84)90044-X
Campos, B. C. S., Vilalva, F. C. J., Nascimento, M. A. L., Galindo, A. C. (2016). Crystallization conditions of porphyritic high-K calc-alkaline granitoids in the extreme northeastern Borborema Province, NE Brazil, and geodynamic implications. Journal of South American Earth Sciences, 70, 224-236. https://doi.org/10.1016/j.jsames.2016.05.010

Campos, T. F. C. (1997). Geoquímica de Rochas Granitóides e Seus Minerais do Batólito da Serra Negra do Norte-RNe Rio Espinharas-PB, Nordeste do Brasil. Tese (Doutorado). Porto Alegre: Instituto de Geociências - UFRGS, 408 p.

Campos, T. F. C., Neiva, A. M. R., Nardi, L. S. V. (2000). Geochemistry of granites and their minerals from Serra Negra do Norte Pluton, northeastern Brazil. Chemie der Erde, 60(4), 279-303.

Chappell, B. W., Bryant, C. J., Wyborn, D., White, A. J. R., Williams, I. S. (1998). High-and low-temperature I-type granites. Resource Geology, 48(4), 225-235. https://doi. org/10.1111/j.1751-3928.1998.tb00020.x

Claiborne, L. L., Miller, C. F., Wooden, J. L. (2010). Trace element composition of igneous zircon: a thermal and compositional record of the accumulation and evolution of a large silicic batholith, Spirit Mountain, Nevada. Contributions to Mineralogy and Petrology, 160(4), 511-531. https://doi. org/10.1007/s00410-010-0491-5

Clemens, J. D., Holloway, J. R., White, A. J. R. (1986). Origin of an A-type granite: experimental constraints. American Mineralogist, 71(3), 317-324.

Cunha, I. R. V., Dall'Agnol, R., Feio, G. R. L. (2016). Mineral chemistry and magnetic petrology of the Archean Planalto Suite, Carajas Province-Amazonian Craton: Implications for the evolution of ferroan Archean granites. Journal of South American Earth Sciences, 67, 100-121. https://doi. org/10.1016/j.jsames.2016.01.007

Cunha, J. A. P., Souza, Z. S., Moreira, J. A. M., Valcácio, S. N. (2018). Mecanismo de colocação e auréola termal provocada pelo plúton Ediacarano Catingueira, Província Borborema, Nordeste do Brasil. Geologia USP. Série Cientifica, 18(4), 209-226. https://doi.org/10.11606/issn.2316-9095.v18-143141

Dalan, C. A., Vilalva, F. C. J., Nascimento, M. A. L. (2017). Condições Redox de Cristalização do Plúton Caxexa, Província Borborema, APartir da Substituição Hedenbergita $\leftrightarrow$ Andradita. $27^{\circ}$ Simpósio de Geologia do Nordeste. Anais, resumo RMG166. João Pessoa: Sociedade Brasileira de Geologia. Disponível em: $<$ www.geologiadonordeste.com.br/safetyarea/v3.0/trabalhos/ resumo_pdf/171.pdf>. Acesso em: 12 jul. 2018. 
Dall'Agnol, R., Oliveira, D. C. (2007). Oxidized, magnetiteseries, rapakivi-type granites of Carajás, Brazil: implications for classification and petrogenesis of A-type granites. Lithos, 93(3-4), 215-233. https://doi.org/10.1016/j. lithos.2006.03.065

Dall'Agnol, R., Scaillet, B., Pichavant, M. (1999). An experimental study of a lower Proterozoic A-type granite from the Eastern Amazonian Craton, Brazil. Journal of Petrology, 40(11), 1673-1698. https://doi.org/10.1093/ petroj/40.11.1673

De La Roche, H., Leterrier, J., Granclaude, P., Marchal, M. (1980). A classification of volcanic and plutonic rocks using R1-R2 diagram and major element analyses. Its relationship with current nomenclature. Chemical Geology, 29(1-4), 183-210. https://doi. org/10.1016/0009-2541(80)90020-0

Deer, W. A., Howie, R. A., Zussman, J. (2013). An introduction to the rock-forming minerals. 3. ed. Londres: The Mineralogical Society, 498 p.

Dou, J. Z., Zhang, H. F., Tong, Y., Wang, F., Chen, F. K., Li, S. R. (2018). Application of geothermo-barometers to Mesozoic granitoids in the Jiaodong Peninsula, eastern China: Criteria for selecting methods of pressure estimation and implications for crustal exhumation. Journal of Asian Earth Sciences, 160, 271-286. https://doi.org/10.1016/j. jseaes.2018.01.019

Droop, G. T. R. (1987). A general equation for estimating $\mathrm{Fe}^{3+}$ concentrations in ferromagnesian silicates and oxides from microprobe analyses, using stoichiometric criteria. Mineralogical Magazine, 51(361), 431-435. https://doi. org/10.1180/minmag.1987.051.361.10

Dymek, R. F. (1983). Titanium, aluminum and interlayer cation substitutions in biotite from high-grade gneisses' West Greenland. American Mineralogist, 69(8), 880-399. https:// doi.org/10.1180/minmag.1987.051.361.10

Eby, G. N. (1992). Chemical subdivision of the A-type granitoids: petrogenetic and tectonic implications. Geology, 20(7), 641644. https://doi.org/10.1130/0091-7613(1992)020<0641:CSO TAT $>2.3 . \mathrm{CO} ; 2$

Ferreira, V. P., Sial, A. N., Pimentel, M. M., Armstrong, R., Spicuzza, M. J., Guimarães, I. P., Silva Filho, A. F. (2011). Contrasting sources and PT crystallization conditions of epidote-bearing granitic rocks, northeastern Brazil: $\mathrm{O}, \mathrm{Sr}$, and $\mathrm{Nd}$ isotopes. Lithos, 121(1-4), 189-201. https://doi. org/10.1016/j.lithos.2010.11.002
Frost, B.R., Barnes, C.G., Collins, W.J., Arculus, R.J., Ellis, D.J., Frost, C.D. (2001). A chemical classification for granitic rocks. Journal of Petrology, 42(11), 2033-2048. https://doi. org/10.1093/petrology/42.11.2033

Galindo, A. C., Alves Silva, F. C., Souza, Z. S. (2012). Química mineral de leucomicrogranitos neoproterozóicos do Domínio Rio Grande do Norte (DRN). Geochimica Brasiliensis, 26(1), 19-28. http://dx.doi.org/10.21715/gb.v26i1.347

Galindo, A. C., Sá, J. M. (2000). Contexto tectônico e geoquímico do granitóide Catingueira: um magmatismo alcalino-peralcalino no limite norte da Zona Transversal da Província Borborema. Geochimica Brasiliensis, 14(1), 1-21. http://dx.doi.org/10.21715/gb.v14i1.164

Gervasoni, F., Klemme, S., Rocha-Júnior, E. R., Berndt, J. (2016). Zircon saturation in silicate melts: a new and improved model for aluminous and alkaline melts. Contributions to Mineralogy and Petrology, 171(3), 21. https://doi.org/10.1007/s00410-016-1227-y

Gualda, G. A., Ghiorso, M. S., Lemons, R. V., Carley, T. L. (2012). Rhyolite-MELTS: a modified calibration of MELTS optimized for silica-rich, fluid-bearing magmatic systems. Journal of Petrology, 53(5), 875-890. https://doi. org/10.1093/petrology/egr080

Gualda, G. A. R., Vlach, S. R. F. (2007). The Serra da Graciosa A-type Granites and Syenites, southern Brazil. Part 2: Petrographic and mineralogical evolution of the alkaline and aluminous associations. Lithos, 93(3-4), 310327. https://doi.org/10.1016/j.lithos.2006.06.002

Guimarães, I. P., Silva Filho, A. F., Almeida, C. N., Van Schmus, W. R., Araújo, J. M., Melo, S. C., Melo, E. B. (2004). Brasiliano (Pan-African) granitic magmatism in the Pajeú-Paraíba belt, Northeast Brazil: an isotopic and geochronological approach. Precambrian Research, 135(12), 23-53. https://doi.org/10.1016/j.precamres.2004.07.004

Gustafson, W. I. (1974). The stability of andradite, hedenbergite, and related minerals in the system $\mathrm{Ca}-\mathrm{Fe}-$ Si-O-H. Journal of Petrology, 15(3), 455-496. https://doi. org/10.1093/petrology/15.3.455

Hammarstrom, J. M., Zen, E. A. (1986). Aluminum in hornblende: an empirical igneous geobarometer. American Mineralogist, 71(11-12), 1297-1313.

Harrison, T. M., Watson, E. B. (1984). The behavior of apatite during crustal anatexis: equilibrium and kinetic considerations. Geochimica et Cosmochimica Acta, 48(7), 1467-1477. https://doi.org/10.1016/0016-7037(84)90403-4. 
Harrison, T. M., Watson, E. B., Aikman, A. B. (2007). Temperature spectra of zircon crystallization in plutonic rocks. Geology, 35(7), 635-638. https://doi.org/10.1130/ G23505A.1

Hawthorne, F. C., Oberti, R., Harlow, G. E., Maresch, W. V., Martin, R. F., Schumacher, J. C., Welch, M. D. (2012). Nomenclature of the amphibole supergroup. American Mineralogist, 97(11-12), 2031-2048. https://doi.org/10.2138/ am.2012.4276

Hayden, L. A., Watson, E. B., Wark, D. A. (2008). A thermobarometer for sphene (titanite). Contributions to Mineralogy and Petrology, 155(4), 529-540. https://doi. org/10.1007/s00410-007-0256-y

Holland, T., Blundy, J. (1994). Non-ideal interactions in calcic amphiboles and their bearing on amphibole-plagioclase thermometry. Contributions to Mineralogy and Petrology, 116(4), 433-447. https://doi.org/10.1007/BF00310910

Hollanda, M. H. B. M. (1998). Mecanismos de Alojamentos de Magmas Granitoides: Exemplo do Plúton de Japi (RN). Tese (Doutorado). Natal: Pós-Graduação em Geodinâmica e Geofísica - UFRN, 126 p. Disponível em: <https:// repositorio.ufrn.br/jspui/handle/123456789/18763>. Acesso em: 15 jan. 2018.

Hollanda, M. H. B. M., Jardim de Sá, E. F., Galindo, A. C., Souza, Z. S. (1999). Shear zone control on the emplacement of granitoid magmas: an example from the Japi Complex, Seridó Belt, NE Brazil. Revista Brasileira de Geociências, 29(1), 41-46. https://doi. org/10.25249/0375-7536.1999294146

Hollister, L. S., Grissom, G. C., Peters, E. K., Stowell, H. H., Sisson, V. B. (1987). Confirmation of the empirical correlation of $\mathrm{Al}$ in hornblende with pressure of solidification of calc-alkaline plutons. American Mineralogist, 72(3-4), 231-239.

Holtz, F., Johannes, W., Tamic, N., Behrens, H. (2001). Maximum and minimum water contents of granitic melts generated in the crust: a reevaluation and implications. Lithos, 56(1), 1-14. https://doi.org/10.1016/ S0024-4937(00)00056-6

Jardim de Sá, E. F., Trindade, R. I. F., Hollanda, M. H. B. M., Araújo, J. M. M., Galindo, A. C., Amaro, V. E., Souza, Z. S., Vigneresse, J.-L, Lardeaux, J. M. (1999). Brasiliano syntectonic alkaline granites emplaced in a strike slip/ extensional setting (Eastern Seridó Belt, NE Brazil). Anais da Academia Brasileira de Ciências, 71(1), 17-28.
Johnson, M. C., Rutherford, M. J. (1989). Experimentally determined conditions in the Fish Canyon Tuff, Colorado, magma chamber. Journal of Petrology, 30(3), 711-737. https://doi.org/10.1093/petrology/30.3.711

King, P. L., Chappell, B. W., Allen, C. M., White, A. J. R. (2001). Are A-type granites the high-emperature felsic granites? Evidence from fractionated granites of the Wangrah Suite. Australian Journal of Earth Sciences, 48(4), 501-514. https://doi.org/10.1046/j.1440-0952.2001.00881.x

King, P. L., White, A. J. R., Chappell, B. W., Allen, C. M. (1997). Characterization and origin of aluminous A-type granites from the Lachlan Fold Belt, southeastern Australia. Journal of Petrology, 38(3), 371-391. https://doi.org/10.1093/ petroj/38.3.371

Lages, G. D. A., Marinho, M. D. S., Nascimento, M. A. L., Medeiros, V. C. D., Dantas, E. L. (2016). Geochronology and structural and petrological features of the Bravo Pluton, Central Domain of the Borborema Province, Northeast Brazil: an early trans-alkaline granite in the post-collisional stage of the Brasiliano Orogeny. Brazilian Journal of Geology, 46(1), 41-61. http://dx.doi. org/10.1590/2317-4889201620150033

Lima, J. V., Guimarães, I. D. P., Santos, L., Amorim, J. V. A., Farias, D. J. S. (2017). Geochemical and isotopic characterization of the granitic magmatism along the Remígio-Pocinhos shear zone, Borborema Province, NE Brazil. Journal of South American Earth Sciences, 75, 116133. https://doi.org/10.1016/j.jsames.2017.02.004

Luth, W. C., Jahns, R. H., Tuttle, O. F. (1964). The granite system at pressures of 4 to 10 kilobars. Journal of Geophysical Research, 69(4), 759-773. https://doi. org/10.1029/JZ069i004p00759

Manning, D. A. C. (1981). The effect of fluorine on liquidus phase relationships in the system Qz-Ab-Or with excess water at $1 \mathrm{~kb}$. Contributions to Mineralogy and Petrology, 76(2), 206-215. https://doi.org/10.1007/BF00371960

Miller, C. F., McDowell, S. M., Mapes, R. W. (2003). Hot and cold granites? Implications of zircon saturation temperatures and preservation of nheritance. Geology, 31(6), 529-532. https://doi.org/10.1130/0091-7613(2003)031<0529:HAC $\mathrm{GIO}>2.0 . \mathrm{CO} ; 2$

Moecher, D. P., McDowell, S. M., Samson, S. D., Miller, C. F. (2014). Ti-in-zircon thermometry and crystallization modeling support hot Grenville granite hypothesis. Geology, 42(3), 267-270. https://doi.org/10.1130/G35156.1 
Mutch, E. J. F., Blundy, J. D., Tattitch, B. C., Cooper, F. J., Brooker, R. A. (2016). An experimental study of amphibole stability in low-pressure granitic magmas and a revised Al-in-hornblende geobarometer. Contributions to Mineralogy and Petrology, 171(10), 85. https://doi. org/10.1007/s00410-016-1298-9

Naney, M. T. (1983). Phase equilibria of rock-forming ferromagnesian silicates in granitic systems. American Journal of Science, 283(10), 993-1033. https://doi.org/10.2475/ ajs.283.10.993

Nascimento, M. A. L. (2000). Petrologia do Magmatismo Tardi-brasiliano no Maciço São José de Campestre (RN$P B)$, com ênfase no Plúton Alcalino Caxexa. Dissertação (Mestrado). Natal: Pós-Graduação em Geodinâmica e Geofísica-UFRN, 142 p. Disponível em: $<$ https://repositorio. ufrn.br/jspui/handle/123456789/18752>. Acesso em: 01 dez. 2017.

Nascimento, M. A. L., Galindo, A. C., Medeiros, V. C. (2015). Ediacaran to Cambrian magmatic suites in the Rio Grande do Norte domain, extreme Northeastern Borborema Province (NE of Brazil): Current knowledge. Journal of South American Earth Sciences, 58, 281-299. https://doi. org/10.1016/j.jsames.2014.09.008

Nascimento, M. A. L., Souza, Z. S., Hollanda, M. H. B. M., Pimentel, M. M., Macedo, M. H. F., Nascimento, R. S. C., Galindo, A. C. (2001). Geocronologia e assinatura isotópica $\mathrm{Rb}-\mathrm{Sr}$ e $\mathrm{Sm}-\mathrm{Nd}$ do magmatismo alcalino neoproterozóico no Maciço São José de Campestre, Nordeste da Província Borborema (NE do Brasil). Estudos Geológicos, 11(1), 67-79.

Nascimento, M. A. L., Souza, Z. S., Nascimento, R. S. C., Galindo, A. C. (2003). Química mineral e evolução petrológica do magmatismo alcalino neoproterozóico do maciço São José de Campestre (RN-PB), extremo NE da Província Borborema. Revista Brasileira de Geociências, 33(2), 225236. https://doi.org/10.25249/0375-7536.2003332225236

Nascimento, R. S. C. (1998). Petrologia dos Granitóides Brasilianos Associados à Zona de Cisalhamento RemígioPocinhos (PB). Dissertação (Mestrado). Natal: Pós-Graduação em Geodinâmica e Geofísica - UFRN, 174 p. Disponível em: $<$ https://repositorio.ufrn.br/jspui/handle/123456789/18762>. Acesso em: 01 dez. 2017.

Nascimento, R. S. C. D., McReath, I., Galindo, A. C. (2010). Relationships between shearing and granitic magma emplacement: the Remígio-Pocinhos shear zone in the São José do Campestre massif, NE Brazil. Geologia
USP. Série Cientifica, 10(3), 3-10. https://doi.org/10.5327/ Z1519-874X2010000300001

Njonfang, E., Nono, A. (2003). Clinopyroxene from some felsic alkaline rocks of the Cameroon Line, central Africa: petrological implications. European Journal of Mineralogy, 15(3), 527542. https://doi.org/10.1127/0935-1221/2003/0015-0527

Patiño-Douce, A. (1997). Generation of metaluminous A-type granites by low pressure melting of calcalkaline granitoids. Geology, 25(8), 743-746. https://doi. org/10.1130/0091-7613(1997)025<0743:GOMATG >2.3.CO;2

Pearce, J. (1996). Sources and settings of granitic rocks. Episodes, 19(4), 120-125.

Pearce, J. A., Harris, N. B., Tindle, A. G. (1984). Trace element discrimination diagrams for the tectonic interpretation of granitic rocks. Journal of Petrology, 25(4), 956-983. https:// doi.org/10.1093/petrology/25.4.956

Putirka, K. D. (2008). Thermometers and barometers for volcanic systems. Reviews in Mineralogy and Geochemistry, 69(1), 61-120. https://doi.org/10.2138/rmg.2008.69.3

Rämö, O. T., Dall'Agnol, R., Macambira, M. J., Leite, A. A., Oliveira, D. C. (2002). 1.88 Ga oxidized A-type granites of the Rio Maria region, eastern Amazonian craton, Brazil: positively anorogenic!. The Journal of Geology, 110(5), 603-610. http://dx.doi.org/10.1086/341761

Ridolfi, F., Renzulli, A., Puerini, M. (2010). Stability and chemical equilibrium of amphibole in calc-alkaline magmas: an overview, new thermobarometric formulations and application to subduction-related volcanoes. Contributions to Mineralogy and Petrology, 160(1), 45-66. https://doi. org/10.1007/s00410-009-0465-7

Schmidt, M. W. (1992). Amphibole composition in tonalite as a function of pressure: an experimental calibration of the Al-inhornblende barometer. Contributions to Mineralogy and Petrology, 110(2-3), 304-310. https://doi.org/10.1007/BF00310745

Schmidt, M. W., Thompson, A. B. (1996). Epidote in calcalkaline magmas: An experimental study of stability, phase relationships, and the role of epidote in magmatic evolution. American Mineralogist, 81(3-4), 462-474. https://doi. org/10.2138/am-1996-3-420

Schumacher, J. C. (1997). The estimation of ferric iron in electron microprobe analysis of amphiboles. Mineralogical Magazine, 61(405), 312-321. https://doi.org/10.1017/ S0026461X00011397 
Sial, A. N., Vasconcelos, P. M., Ferreira, V. P., Pessoa, R. R., Brasilino, R. G., Morais Neto, J. M. (2008). Geochronological and mineralogical constraints on depth of emplacement and ascencion rates of epidote-bearing magmas from northeastern Brazil. Lithos, 105(3-4), 225-238. https://doi.org/10.1016/j. lithos.2008.04.002

Siégel, C., Bryan, S. E., Allen, C. M., Gust, D. A. (2018). Use and abuse of zircon-based thermometers: A critical review and a recommended approach to identify antecrystic zircons. Earth-Science Reviews, 176, 87-116. https://doi. org/10.1016/j.earscirev.2017.08.011

Souza, V. O. (2016). Magmatismo Granítico na Porção Central do Domínio Rio Piranhas-Seridó, Província Borborema: Geologia e Petrologia do Stock Flores (RN). Dissertação (Mestrado). Natal: Pós-Graduação em Geodinâmica e Geofísica-UFRN. Disponível em: $<$ https://repositorio.ufrn. br/jspui/handle/123456789/21578>. Acesso em: 15 jan. 2017.

Souza, V. O., Galindo, A. C., Alves da Silva, F. C. (2017). O Stock Flores: Exemplo de magmatismo granítico tipo-A no Domínio Rio Piranhas-Seridó, NE da Província Borborema. Pesquisas em Geociências, 44(2), 345-366. https://doi. org/10.22456/1807-9806.78278

Souza, Z. S., Kalsbeek, F., Deng, X.D., Frei, R., Kokfelt, T. F., Dantas, E. L., Li, J.W., Pimentel, M. M., Galindo, A. C. (2016). Generation of continental crust in the northern part of the Borborema Province, northeastern Brazil, from Archaean to Neoproterozoic. Journal of South American Earth Sciences, 68, 68-96. https://doi.org/10.1016/j.jsames.2015.10.006

Souza, Z. S., Montel, J. M., Gioia, S. M. L. C., Hollanda, M. H. B. M., Nascimento, M. A. L., Jardim de Sá, E. F., Amaro, V. E., Pimentel, M. M., Lardeaux, J.-M., Veschambre, M. (2006). Electron microprobe dating of monazite from high-T shear zones in the São José de Campestre Massif, NE Brazil. Gondwana Research, 9(4), 441-455.https://doi.org/10.1016/j.gr.2005.11.008

Steiner, J. C., Jahns, R. H., Luth, W. C. (1975). Crystallization of alkali feldspar and quartz in the haplogranite system $\mathrm{NaAlSi}_{3} \mathrm{O}_{8}-\mathrm{KAlSi}_{3} \mathrm{O}_{8}-\mathrm{SiO}_{2}-\mathrm{H}_{2} \mathrm{O}$ at $4 \mathrm{~kb}$. Geological
Society of America Bulletin, 86(1), 83-98. https://doi. org/10.1130/0016-7606(1975)86<83:COAFAQ >2.0.CO;2.

Tuttle, O. F., Bowen, N. L. (1958). Origin of Granite in the Light of Experimental Studies in the System NaAlSi3O8KAlSi3O8-SiO2-H2O. Geological Society of America Memoir. 74. https://doi.org/10.1130/MEM74-p1

van Achterbergh, E., Ryan, C. G., Jackson, S. E., Griffin, W. (2001). Data reduction software for LA-ICP-MS. In: Sylvester, P. (Ed.), Laser Ablation ICPMS in the Earth Sciences. Mineralogical Association of Canada, Short Course Series, 29, 239-243.

Villaseca, C., Orejana, D., Paterson, B.A. (2007). ZrLREE rich minerals in residual peraluminous granulites, another factor in the origin of low $\mathrm{Zr}$-LREE granitic melts? Lithos, 96(3-4), 375-386. https://doi.org/10.1016/j. lithos.2006.11.002

Watson, E. B., Harrison, T. M. (1983). Zircon saturation revisited: temperature and composition effects in a variety of crustal magma types. Earth and Planetary Science Letters, 64(2), 295-304. https://doi.org/10.1016/0012-821X(83)90211-X

Wones, D. R. (1989). Significance of the assemblage titanite+ magnetite + quartz in granitic rocks. American Mineralogist, 74(7), 744-749.

Yang, X. M. (2017). Estimation of crystallization pressure of granite intrusions. Lithos, 286-287, 324-329. http://dx.doi. org/10.1016/j.lithos.2017.06.018

Zen, E., Hammarstrom, J. M. (1988). Plumbing the depth of plutons by magmatic epidote \pm hornblende association: a cautionary review and an example from Round Valley Pluton, Western Idaho. In: Geological Society of America, Rocky Mountain Section Annual Meeting, n. 20, 475-476.

Zhang, Z., Saxena, S. K. (1991). Thermodynamic properties of andradite and application to skarn with coexisting andradite and hedenbergite. Contributions to Mineralogy and Petrology, 107(2), 255-263. https://doi.org/10.1007/BF00310711 